Article

\title{
Corrosion-Resistant Steel-MgO Composites as Refractory Materials for Molten Aluminum Alloys
}

\author{
Piotr Malczyk ${ }^{1, *}$, Tilo Zienert ${ }^{1}{ }^{1}$, Florian Kerber ${ }^{1}$, Christian Weigelt ${ }^{1}$, Sven-Olaf Sauke ${ }^{2}$, \\ Hubertus Semrau ${ }^{2}$ and Christos G. Aneziris ${ }^{1}$ \\ 1 Institute of Ceramic, Glass and Construction Materials, TU Bergakademie Freiberg, Agricolastr. 17, \\ 09599 Freiberg, Germany; tilo.zienert@ikgb.tu-freiberg.de (T.Z.); florian.kerber@ikgb.tu-freiberg.de (F.K.); \\ christian.weigelt@ikgb.tu-freiberg.de (C.W.); aneziris@ikgb.tu-freiberg.de (C.G.A.) \\ 2 ZPF GmbH, Petersaecher 4-6, 74963 Siegelsbach, Germany; sosauke@saukesemrau.de (S.-O.S.); \\ prof_semrau@semrau.se (H.S.) \\ * Correspondence: piotr.malczyk@ikgb.tu-freiberg.de; Tel.: +49-37-3139-3626
}

Received: 11 September 2020; Accepted: 20 October 2020; Published: 23 October 2020

\begin{abstract}
In this study, a novel metal matrix composite based on $60 \mathrm{vol} \% 316 \mathrm{~L}$ stainless steel and $40 \mathrm{vol} \% \mathrm{MgO}$ manufactured by powder metallurgy technology was developed. The corrosion resistance of the developed steel-MgO composite material against molten aluminum alloy AlSi7Mg0.3 was investigated by means of wettability tests and long-term crucible corrosion tests. The wettability tests were carried out using the sessile drop method with the capillary purification technique in a hot-stage microscope (HSM). Static corrosion tests were performed in molten aluminum alloy at $850{ }^{\circ} \mathrm{C}$ for $168 \mathrm{~h}$ to evaluate the impact of pre-oxidation of the composite surface on the corrosion resistance. The pre-oxidation of steel-MgO composites was carried out at 850 and $1000{ }^{\circ} \mathrm{C}$ for $24 \mathrm{~h}$, based on preliminary investigations using thermogravimetry (TG) and dilatometry. The influence of the pre-oxidation on the composite structure, the corrosion resistance, and the phase formation at the interface between the steel-MgO composite and aluminum alloy was analyzed using SEM/EDS and XRD. The impact of the steel-MgO composite material on the composition of the aluminum alloy regarding the type, size, and quantity of the formed precipitations was investigated with the aid of ASPEX PSEM/AFA and SEM/EBSD. It was revealed that the pre-oxidation of the steel-MgO composite at $1000{ }^{\circ} \mathrm{C}$ induced the formation of stable $\mathrm{MgO}-\mathrm{FeO}$ solid solutions on its surface, leading to a significant increase of long-term corrosion resistance against the liquid aluminum alloy.
\end{abstract}

Keywords: metal matrix composites; molten aluminum; corrosion; wettability; surface oxidation

\section{Introduction}

The chemical reactivity of molten aluminum alloys in contact with steel-based materials is well known and has already been widely studied [1-4]. A short contact time of steel with liquid aluminum is utilized for the formation of very robust, protective Fe-Al intermetallic layers on steel parts [5-8]. However, longer contact times of steel-based materials with liquid aluminum cause rapid dissolution of the steel and damage to the parts $[2,4,9]$.

The wettability of metals and their alloys can be studied using various methods $[10,11]$. The wetting angle, which is measured between the molten metal and the substrate, is often used for the estimation of corrosion behavior or adhesion [11-14]. The wetting angle depends on the surface characteristics of the substrate, as well as on the composition and viscosity of the melt at a given temperature and atmosphere [15-17]. The viscosity of Al-Si alloys at casting temperatures is very low and decreases with the content of $\operatorname{Si}[16,18]$, entailing deep infiltration of the melt into the substrate and subsequent corrosion phenomena. The chemical interactions cause serious problems in the determination of 
aluminum wetting angles [13]. By means of sessile drop method with the capillary purification technique, the melt drop comes into contact with the substrate after reaching the melting point and the measurement is performed immediately after the deposition of the drop.

For the investigation of long-term corrosion in melts, static crucible tests or dynamic finger immersion tests are applied [19-21]. The immersion tests mostly take less than $12 \mathrm{~h}$. The crucible corrosion test is commonly used in the field of refractory oxide ceramics and is characterized by significantly longer testing times [19,21,22]. For example, Sellers et al. [23] applied the crucible method to study the corrosion of 316L stainless steel and Hastelloy-N superalloy in a molten LiF-NaF-KF salt eutectic. No studies on the corrosion resistance of stainless steel against molten aluminum or aluminum alloy using long-term crucible tests were found in the literature search.

It is obvious that pure steel is unable to withstand even brief contact with molten aluminum $[1,2,9]$. Liquid aluminum alloy dissolves iron and forms complex phases in the ternary Al-Si-Fe system [3,24,25]. The dissolution of steel is continuously progressing as a function of time and does not omit other steel elements such as chromium or nickel [4,26-29]. Aluminum alloys also reduce most oxides [4, $30,31]$. Therefore, coatings applied on steel are sufficient only for a short period of contact with the melt $[1,13,31,32]$.

Conventional refractory materials used for contact with molten aluminum and its alloys in different kind of furnaces are based on coarse-grained alumina-mullite castables with antiwetting agents to reduce the infiltration phenomena. The drying and prefiring processes used for the castables are very time-consuming and can cause internal stresses, leading to cracking and subsequent failure of the refractory product. Moreover, the thermal shock resistance of such castables is very often insufficient for the demanding, continuously changing thermal conditions of metallurgical operations [33,34].

Steel-ceramic composites benefit from the synergy between the steel and the refractory ceramics, and are characterized by good machinability, higher ductility, and advantageous thermomechanical properties, leading to better thermal shock resistance. The addition of ceramics to the steel can increase the corrosion resistance against molten aluminum alloy [35]. Furthermore, multiple studies in the field of steel-ceramic composites present their ability to be produced in a made-to-order fashion [36-38]. Additionally, their ability to form a reliable protective layer that can not be infiltrated and corroded by aluminum alloys makes steel-ceramic composites favorable substitutes for conventional refractory ceramics, especially for applications requiring refractory parts with sophisticated shapes, such as stirrers and lances. According to Fabrichnaya [39], magnesium oxide in contact with iron oxides forms complex $\mathrm{MgO}-\mathrm{FeO}$ solid solutions or spinel structures based on $\mathrm{MgFe}_{2} \mathrm{O}_{4}$. This study focuses on the development of steel matrix composites reinforced by $\mathrm{MgO}$ and on the investigation of their corrosion resistance, particularly the contribution of an in situ formation of a passivated mixed oxide layer on the surface of the steel-MgO composite due to the pre-oxidation.

\section{Materials and Methods}

\subsection{Materials and Manufacturing}

The powder mixture used for manufacturing the composite samples consisted of $60 \mathrm{vol} \%$ gas-atomized 316L-FeCr18Ni10Mo3 stainless steel powder (TLS Technik, Bitterfeld-Wolfen, Germany) and $40 \mathrm{vol} \%$ electrofused $\mathrm{MgO}<3 \mu \mathrm{m}, 98 \% \mathrm{MgO}$ (Refratechnik Steel, Duesseldorf, Germany). The mixture is further described as " $316 \mathrm{~L}-40 \mathrm{MgO}^{\prime}$. The composition of the steel powder is listed in Table 1 . Table 2 contains the particle size percentiles and true densities of the raw materials.

Table 1. Composition of 316L stainless steel powder (in wt \%).

\begin{tabular}{ccccccccccc}
\hline Steel & Fe & $\mathbf{C r}$ & $\mathbf{N i}$ & $\mathbf{S i}$ & $\mathbf{M o}$ & $\mathbf{M n}$ & $\mathbf{T i}$ & $\mathbf{N b}$ & $\mathbf{S}$ & Al \\
\hline 316L & Balance & 17.6 & 10.9 & 0.5 & 2.66 & 0.2 & 0.01 & 0.01 & 0.01 & 0.04 \\
\hline
\end{tabular}


Table 2. Particle sizes and densities of the raw materials.

\begin{tabular}{ccccc}
\hline \multirow{2}{*}{ Raw Material } & \multicolumn{3}{c}{ Particle Size in $\boldsymbol{\mu m}$} & Density in $\mathbf{~} \cdot \mathbf{c m}^{\mathbf{3}}$ \\
& $\boldsymbol{D}_{\mathbf{1 0}}$ & $\boldsymbol{D}_{\mathbf{5 0}}$ & $\boldsymbol{D}_{\mathbf{9 0}}$ & (30.94 \\
316L & 4 & 30 & 53 & 3.60 \\
$\mathrm{MgO}$ & 0.7 & 14.5 & 67 & \\
\hline
\end{tabular}

Manufacturing of 316L-40MgO steel-ceramic composites requires a homogenous distribution of both steel and ceramic particles. For this purpose, the powder mixture was dry mixed on a roller mill for $120 \mathrm{~min}$ using $3 \mathrm{~mm}$ and $5 \mathrm{~mm}$ stainless steel mixing balls. The mass of the added balls was related to the mass of the powder mixture, which was equal to $21 \%$ and $16 \%$ for the $5 \mathrm{~mm}$ and for the $3 \mathrm{~mm}$ balls, respectively. After sieving out of the mixing balls, the Zusoplast WE52 liquid temporary additive (Zschimmer and Schwarz, Lahnstein, Germany) and water were stepwisely added to the powder mixture via granulation, ensuring a proper distribution of the binder and increasing the green body strength of the samples. The granulation procedure was carried out in two steps, first at $1600 \mathrm{~min}^{-1}$ for $2 \mathrm{~min}$ and subsequently at $2500 \mathrm{~min}^{-1}$ for $3 \mathrm{~min}$, with the aid of an Eirich EL1 laboratory mixer (Maschinenfabrik Gustav Eirich, Hardheim, Germany).

The prepared composite granulates were pressed into cylindrical samples with the aid of a uniaxial press (Rucks, Glauchau, Germany). The pressing procedure had a consolidation pressure of $100 \mathrm{MPa}$ preceded by two air degassing steps (30 MPa and $60 \mathrm{MPa}$ for $1 \mathrm{~s})$. For wettability tests, the samples with a diameter of $50 \mathrm{~mm}$ and height of $7 \mathrm{~mm}$ were used. The cylinders used for further preparation of crucibles had a diameter of $50 \mathrm{~mm}$ and a height of $50 \mathrm{~mm}$.

After uniaxial pressing, all samples were dried in a convection drying oven. The samples used for wettability tests were dried at $110^{\circ} \mathrm{C}$ for $24 \mathrm{~h}$, whereas the cylinders used for preparation of crucibles were dried in two steps at 40 and $110^{\circ} \mathrm{C}$ for $24 \mathrm{~h}$ each. After drying, a core bore with a diameter of ca. $36 \mathrm{~mm}$ and a depth of ca. $42 \mathrm{~mm}$ was hand drilled to prepare cylindrical crucibles with a wall thickness of 7-8 mm.

The binder removal was carried out in a debinding furnace (Xerion, Berlin, Germany) with heating rates of $2 \mathrm{~K} \cdot \mathrm{min}^{-1}$ to $200{ }^{\circ} \mathrm{C}$ and $0.5 \mathrm{~K} \cdot \mathrm{min}^{-1}$ from 200 to $500{ }^{\circ} \mathrm{C}$, with a holding time of $30 \mathrm{~min}$ and cooling rate of $0.5 \mathrm{~K} \cdot \mathrm{min}^{-1}$. After debinding, the samples were sintered for $2 \mathrm{~h}$ at $1350{ }^{\circ} \mathrm{C}$ using a furnace with a graphite lining (Xerion, Berlin, Germany) under argon atmosphere, with heating and cooling rates of $5 \mathrm{~K} \cdot \mathrm{min}^{-1}$. The mean value of the linear sintering shrinkage was $4 \%$ and the bulk density was $4.76 \mathrm{~g} \cdot \mathrm{cm}^{-3}$. The measurement of the open porosity using an AutoPore V mercury intrusion porosimeter (Micromeritics, Unterschleißheim, Germany) revealed an open porosity of about $21 \%$.

The wettability and corrosion resistance investigations were carried out using common silicon pre-eutectic AlSi7Mg0.3 casting aluminum alloy (TRIMET Aluminum, Essen, Germany). The as-delivered composition of this aluminum alloy is listed in Table 3.

Table 3. Composition of AlSi7Mg0.3 aluminum alloy (in wt \%).

\begin{tabular}{ccccccccccc}
\hline Alloy & Al & Si & Mg & Fe & Cu & Mn & Zn & Ti & Cr & Ni \\
\hline AlSi7Mg0.3 & 92.30 & 7.17 & 0.27 & 0.081 & 0.002 & 0.002 & 0.007 & 0.12 & 0.001 & 0.003 \\
\hline
\end{tabular}

\subsection{Pre-Oxidation as a Surface Treatment}

Both the wettability tests and crucible corrosion tests were performed on samples with two different surface treatments-as-sintered and pre-oxidized. The wettability substrate was pre-oxidized at $850^{\circ} \mathrm{C}$ for $24 \mathrm{~h}$. The steel-MgO composite crucibles for corrosion tests were pre-oxidized at 850 and $1000^{\circ} \mathrm{C}$ for $24 \mathrm{~h}$.

To evaluate suitable pre-oxidation conditions, thermal analyses of $316 \mathrm{~L}-40 \mathrm{MgO}$ were performed using a STA 409 PC calorimeter (Netzsch, Selb, Germany) and a DIL 402 C dilatometer (Netzsch, Selb, 
Germany) under artificial air atmosphere conditions, with a heating rate of $10 \mathrm{~K} \cdot \mathrm{min}^{-1}$ up to $1100{ }^{\circ} \mathrm{C}$. Moreover, to assess the oxidation kinetics, the thermogravimetric and dilatometric measurements were carried out for $24 \mathrm{~h}$ at constant temperatures of 850 and $1000{ }^{\circ} \mathrm{C}$ as functions of time.

\subsection{Wettability Tests}

As a necessary precondition for the measurement of wetting angles, a defined substrate surface is required. Therefore, the surfaces of the sintered substrates were stripped of the sintering oxide layer and polished with sandpapers of different grain sizes down to $8 \mu \mathrm{m}$. After polishing, one of the wettability substrates was pre-oxidized at $8500^{\circ} \mathrm{C}$.

According to Wenzel [15], the equilibrium wetting angle $\Theta_{\mathrm{E}}$ depends on the roughness of the substrate surface as follows:

$$
\Theta_{\mathrm{E}}=\arccos \left(\frac{\cos \Theta_{\mathrm{W}}}{S_{\mathrm{r}}}\right)
$$

where $\Theta_{\mathrm{W}}$ is the apparent (as-measured) wetting angle and $S_{\mathrm{r}}$ is the developed area ratio $\left(S_{\mathrm{r}}=S d r+1\right)[40,41]$. The linear or surficial roughness and the developed area ratio of the substrates were determined using a VK/X-1000 laser scanning microscope with a multifile analyzer (Keyence, Neu-Isenburg, Germany) according to ISO 25178-2-2020 and DIN EN ISO 4287 [40,42].

Wettability tests were performed using the sessile drop method with a capillary purification technique in a hot-stage microscope (HSM) (Raczek, Garbsen, Germany). For this purpose, a suitable capillary purification system was developed (see Figure 1). The capillary system with a pressurizing plunger was built from sintered, silica-free boron nitride with $\mathrm{B}_{2} \mathrm{O}_{3}$ binder (Henze Boron Nitride Products, Lauben, Germany). The capillary system was placed on top of the substrate. The aluminum alloy disc with a height of $3.5 \mathrm{~mm}$ and a diameter of $12 \mathrm{~mm}$ was put into the capillary chamber. The wettability tests were performed with a heating and cooling rate of $10 \mathrm{~K} \cdot \mathrm{min}^{-1}$ under argon atmosphere, with an oxygen level below $0.5 \mathrm{ppm}$. The contact angle was measured $30 \mathrm{~s}$ after the drop release at approximately $630{ }^{\circ} \mathrm{C}$. Afterwards, the wetting angle between the substrate and the sessile drop was continuously recorded during heating up to $850^{\circ} \mathrm{C}$, with a holding time of $30 \mathrm{~min}$ at $850^{\circ} \mathrm{C}$, followed by cooling. An exemplary drop release process is shown in Figure 1.

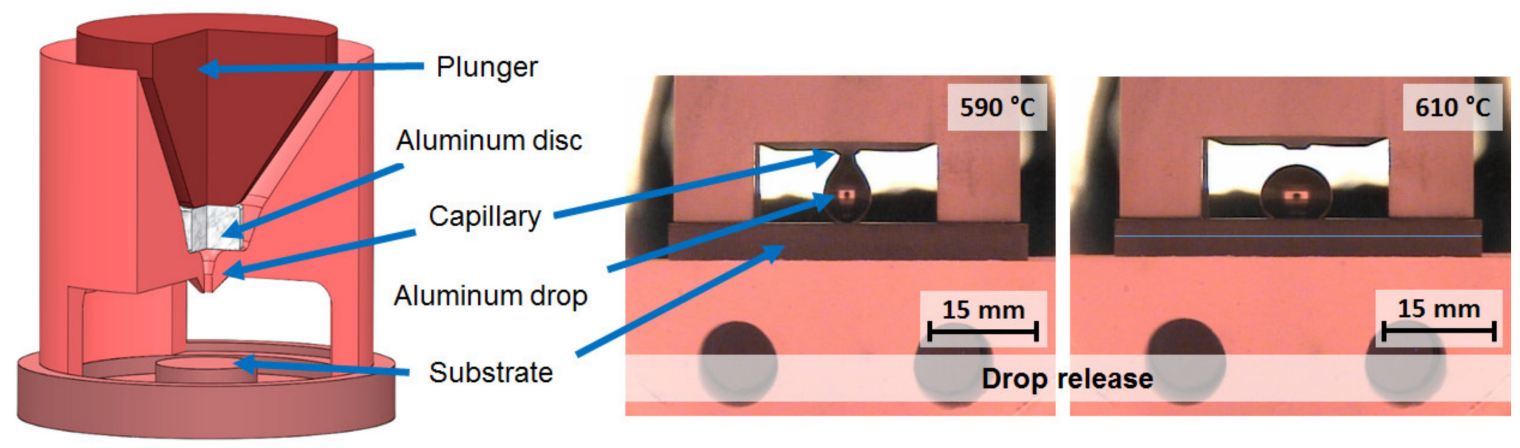

Figure 1. Design of the developed capillary purification system used for wettability tests (left) with exemplary images of drop release (right).

After the wettability tests, the cross-sections of the substrates with solidified aluminum alloy were analyzed using energy-dispersive X-ray spectroscopy with the XL 30 scanning electron microscope (SEM/EDS) (Philips, Eindhoven, Germany).

\subsection{Crucible Corrosion Tests}

The static crucible corrosion tests were performed in a laboratory furnace (Nabertherm, Bremen, Germany). For each crucible test, ca. $100 \mathrm{~g}$ of aluminum alloy AlSi7Mg0.3 was used. The crucibles with aluminum were heated up at $10 \mathrm{~K} \cdot \mathrm{min}^{-1}$ to $850^{\circ} \mathrm{C}$ and held for $168 \mathrm{~h}$ (Figure 2). Subsequently, the samples with aluminum subjected to the corrosion test were vertically cut to analyze the 
cross-sections of the steel-ceramic composite, solidified aluminum, and particularly the interface between the composite and the aluminum alloy.

Initial state

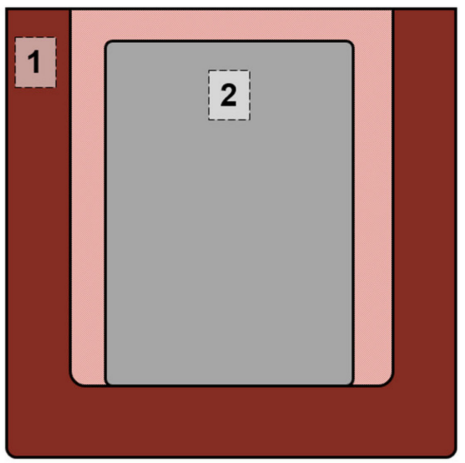

Corrosion test state (molten AISi7Mg0.3 at $850{ }^{\circ} \mathrm{C}$ )

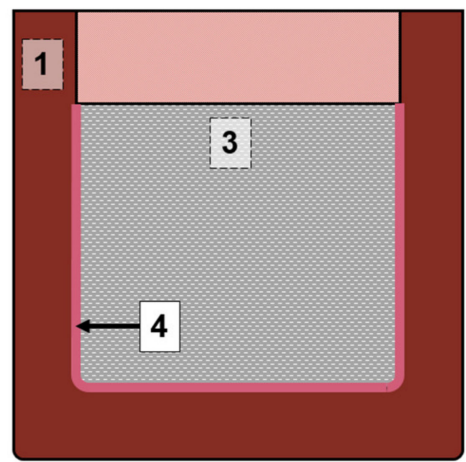

Final state (after the corrosion test)

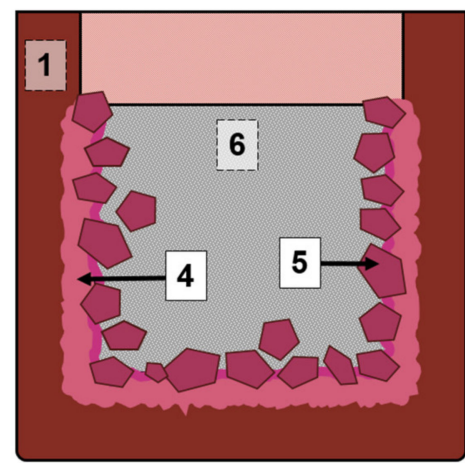

Figure 2. Schematic diagram of the crucible corrosion test: (1) crucible made from the steel-MgO composite, with an outer diameter of $50 \mathrm{~mm}$; (2) solid aluminum alloy; (3) molten aluminum alloy; (4) crucible-aluminum alloy contact interface; (5) corrosion products; (6) solidified aluminum alloy after corrosion test.

The microstructure analysis and the elemental mapping of the solidified aluminum alloy were carried out by SEM/EDS using the XL 30 (Philips, Eindhoven, Germany) and the ASPEX PSEM eXpress (FEI, Delmont, PA, USA) scanning electron microscopes.

X-ray diffraction (XRD) experiments were performed on polished crucible cross-sections with a Bragg-Brentano geometry and with $\mathrm{Cu}-\mathrm{K}_{\alpha}$ radiation between $25^{\circ}$ and $100^{\circ} 2 \Theta$ using the Empyrean DY1946 XRD diffractometer (Malvern Panalytical, Kassel, Germany). By using a divergence slit measuring $1 / 32^{\circ}$, only a very narrow area was irradiated (approximately $0.3 \mathrm{~mm} \times 10 \mathrm{~mm}$ ). The irradiation area was placed parallel to the composite crucible-aluminum alloy interface. Multiple scans at a distance of approximately $25 \mathrm{~mm}$ from the bottom of the crucible, with increments of $1 \mathrm{~mm}$ starting from the crucible side towards the aluminum alloy, were performed to identify and investigate the crucible-aluminum interface.

Phase analysis of the composite crucible was done using Rietveld analysis by applying the structure models listed in Table 4. For clarity, all XRD-detected phases were indicated based on their crystal structure. For example, the $\mathrm{MgO}$ - and $\mathrm{FeO}-$ related solid solutions, which are based on the $\mathrm{NaCl}$ structure, were named halite, instead of periclase and wustite.

Table 4. Overview of used structure models for the Rietveld refinement of 316L-40MgO/AlSi7Mg0.3 samples.

\begin{tabular}{cccc}
\hline Structure Name & Corresponding Phases & Crystal System & ICSD \\
\hline steel-fcc & $\gamma$-Fe & cubic & 53449 \\
steel-bcc & $\alpha$-Fe solid solution & cubic & 52258 \\
halite & $\mathrm{MgO}, \mathrm{MgO}-\mathrm{FeO}$ solid solution & cubic & 52026 \\
corundum & $\mathrm{Cr}_{2} \mathrm{O}_{3}$ & trigonal & 25781 \\
spinel & $\mathrm{Fe}_{3} \mathrm{O}_{4}$ solid solution & cubic & 65341 \\
\hline
\end{tabular}

The phase analysis for the aluminum alloy was performed using electron backscatter diffraction (EBSD) and SEM/EDS of the XL 30 (Philips, Eindhoven, Germany). Detected precipitations resulting from the reaction of aluminum alloy with the steel-MgO composite were indexed for further investigations.

The composition of the aluminum alloy and the assessment of which included the area fraction of the precipitated phases, was investigated by the ASPEX PSEM eXpress (FEI, Delmont, PA, USA) 
using automatic feature analysis (AFA). On each sample, a rectangular section with an area of at least $34 \mathrm{~mm}^{2}$ for the aluminum alloy was scanned and automatically divided into square regions of interest (ROIs) with edge lengths of ca. $111 \mu \mathrm{m}$. Corrosion phases were then identified by material contrast using the ASPEX PSEM back-scatter electron contrast. The detected precipitations were automatically analyzed by EDS and classified into indexed phases according to the restrictions of the elaborated rule file presented in Table 5. The quantification of the area fractions of indexed precipitations was based on the greyscale histogram analysis of 48 ASPEX PSEM/AFA ROIs. The positions of these ROIs within the solidified aluminum alloy and an exemplary phase classification procedure are schematically shown in Figure 3.

Table 5. Rule file for the classification of precipitations in the AlSi7Mg0.3.

\begin{tabular}{cc}
\hline Class & Restrictions in wt $\%$ \\
\hline AlSi7Mg0.3 & $\mathrm{Al}>70$ AND Fe $<20$ \\
$\tau_{6}-\mathrm{AlFeSi}$ & $\mathrm{Al}>20 \mathrm{AND} \mathrm{Si}>1$ AND Fe $>1$ AND $\mathrm{Cr}<1$ AND $\mathrm{Mg}<1$ AND Ni $<5$ \\
$\tau_{5}-\mathrm{Al}(\mathrm{Fe}, \mathrm{Cr}) \mathrm{Si}$ & $\mathrm{Al}>20 \mathrm{AND} \mathrm{Si}>1$ AND Fe $>1$ AND $\mathrm{Cr}>1$ AND $\mathrm{Mg}<1$ AND Ni $<5$ \\
$\pi$-AlSiMgFe & $\mathrm{Al}>20 \mathrm{AND} \mathrm{Si}>1$ AND Fe $>1$ AND $\mathrm{Mg}>1$ AND Ni $<5$ \\
Ni-rich phases & $\mathrm{Ni}>5$ \\
Other precipitations & Balance \\
\hline
\end{tabular}

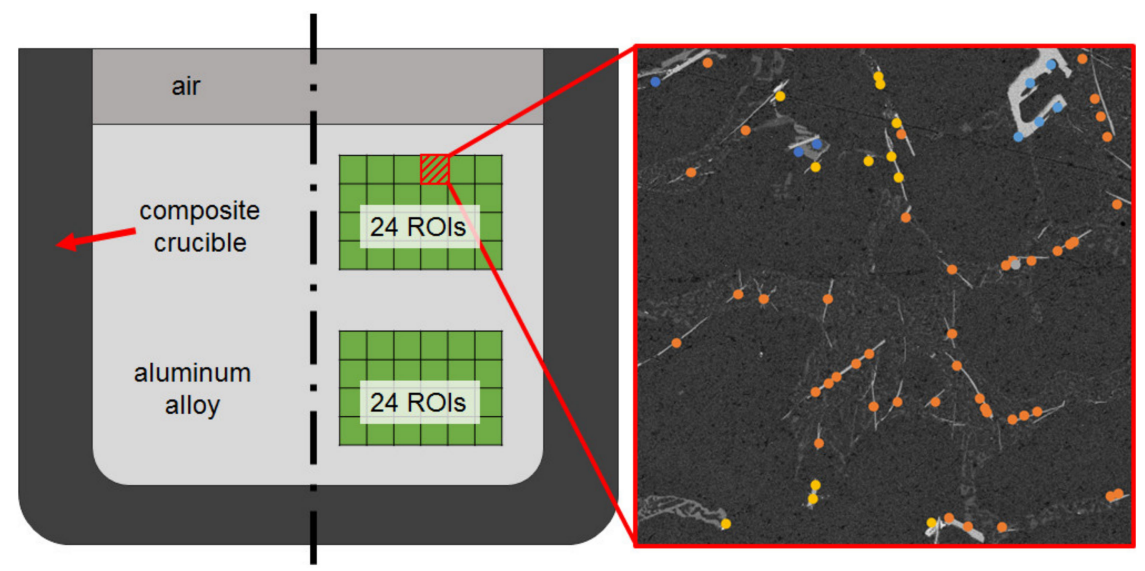

Figure 3. Schematic layout of regions of interest (ROIs) analyzed with ASPEX PSEM/AFA (left), with exemplary classification of detected precipitations within the solidified aluminum alloy (right).

\subsection{Sample Designation}

To distinguish between the samples, the investigated samples were designated according to the type of test and temperature of the surface pre-oxidation. The designations W_0 and W_850 refer to the wettability samples with as-sintered and $850{ }^{\circ} \mathrm{C}$ pre-oxidized surfaces, respectively. The designations C_0, C_850, and C_1000 refer to crucible samples with as-sintered and with $850{ }^{\circ} \mathrm{C}$ and $1000{ }^{\circ} \mathrm{C}$ pre-oxidation surfaces, respectively.

\section{Results and Discussion}

\subsection{Pre-Oxidation}

Pre-oxidation treatment was carried out to induce the formation of a passivation interface layer with increased corrosion resistance against molten aluminum alloy. The kinetics of the process, and hence the results of the pre-oxidation, are dependent on the temperature and duration of the oxidation. During the pre-oxidation, the samples undergo mass, dimensional, and microstructural changes. Figure 4 shows thermogravimetric and dilatometric results for the steel-MgO composite up to $1100{ }^{\circ} \mathrm{C}$, with a heating rate of $10 \mathrm{~K} \cdot \mathrm{min}^{-1}$ under air atmosphere. 

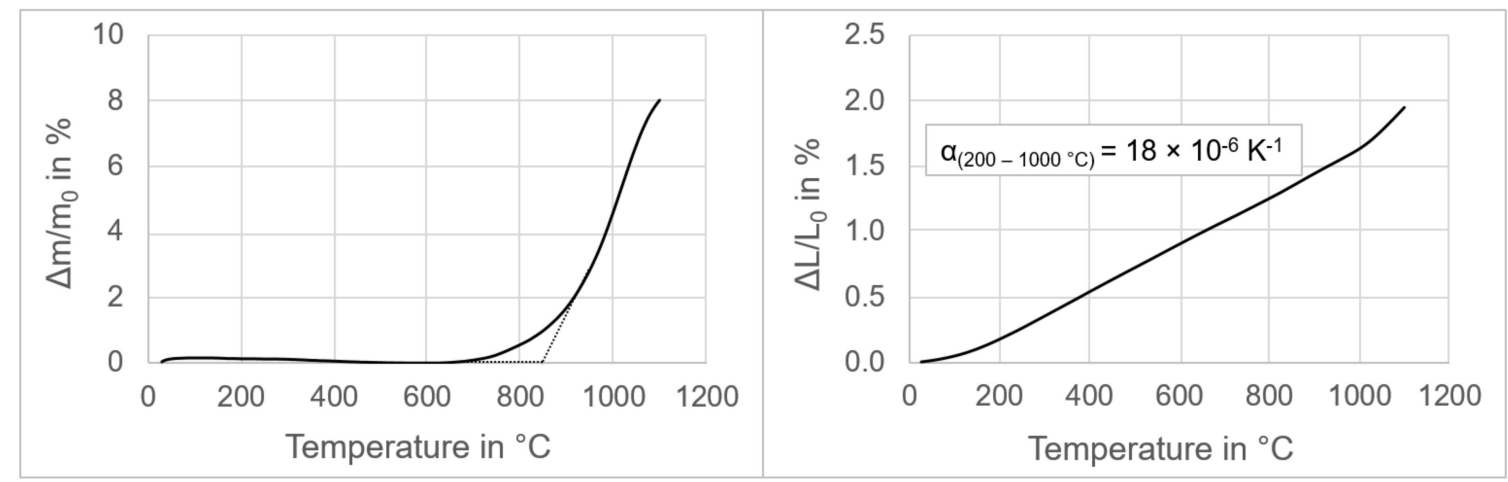

Figure 4. Thermogravimetry (left) and dilatometry (right) analyses of 316L-40MgO composite under air atmosphere as a function of temperature up to $1100^{\circ} \mathrm{C}$.

The composite showed no mass change up to $700{ }^{\circ} \mathrm{C}$. The intersection point for the tangents belonging to the two linear sections of the thermogravimetric curve is at $850{ }^{\circ} \mathrm{C}$. At $1000{ }^{\circ} \mathrm{C}$, the sample already exhibited a mass increase of about $5 \%$. Dilatometry analysis revealed constant thermal expansion of the composite from $200{ }^{\circ} \mathrm{C}$ to $1000{ }^{\circ} \mathrm{C}$, with a linear thermal expansion coefficient of $18 \times 10^{-6} \mathrm{~K}^{-1}$, i.e., similar to the thermal expansion coefficient of the $316 \mathrm{~L}$ stainless steel specified in BS EN 10088-1:2014 [43].

The long-term oxidation behavior of the composite as a function of time is shown in Figure 5.
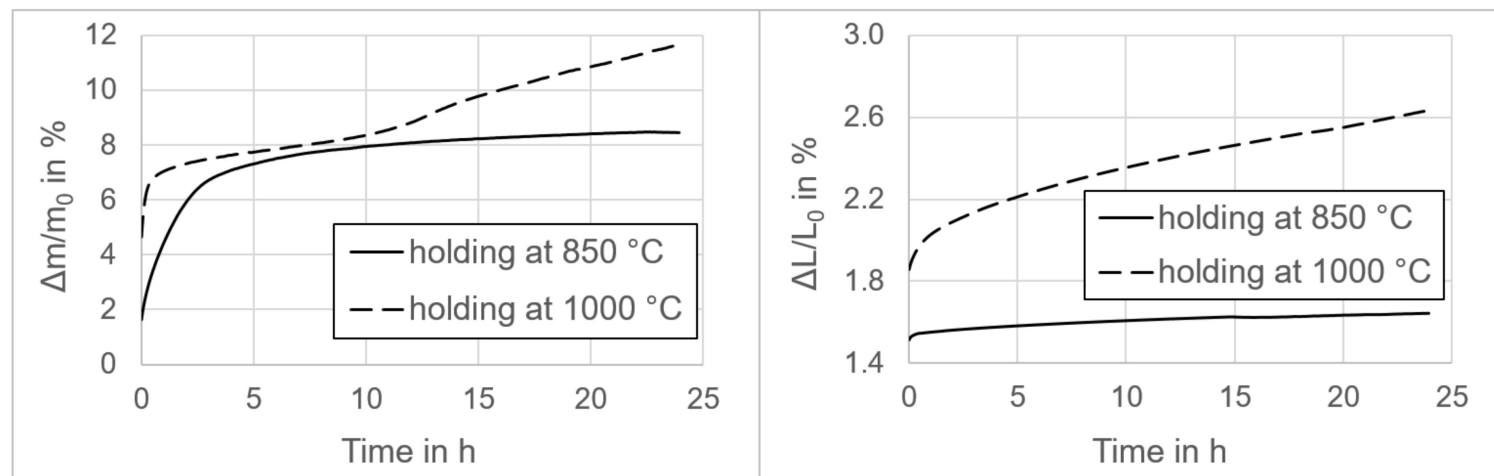

Figure 5. Isothermal thermogravimetry (left) and dilatometry (right) analyses of $316 \mathrm{~L}-40 \mathrm{MgO}$ under air atmosphere as a function of time up to $24 \mathrm{~h}$.

The thermogravimetry analysis of the sample held at $850{ }^{\circ} \mathrm{C}$ proceeded as expected. The thermogravimetric curve had a logarithmic shape with rapid mass gain up to the 3rd hour. Until this time, the sample gained $7 \%$ of the initial mass. After $3 \mathrm{~h}$, the mass gain significantly decreased and over the next $21 \mathrm{~h}$ the sample gained an additional $1.5 \%$ of the initial mass. The initial oxidation originated from the surface and continued through the open pores of the composite. Over the entire time range, the sample gained $8.5 \%$ of the initial mass.

The sample held at $1000{ }^{\circ} \mathrm{C}$ performed as expected up to the 10 th hour, with a gain of $7 \%$ of the initial mass during the first $53 \mathrm{~min}$ of the experiment and exceeding $8.4 \%$ at the 10 th hour. After this, the measurement revealed a sudden change of the curve slope, with a higher mass gain of about $0.2 \%$ per hour. This is probably related to the transformation of the surface structure of the composite, which acquired more oxygen from the atmosphere.

The dilatometry measurements revealed no unexpected thermal expansion behavior. After the 3rd hour of oxidation, both samples showed nearly linear expansion. The expansion rate of the sample held at $850{ }^{\circ} \mathrm{C}$ was ca. $3.5 \times 10^{-3} \% \times \mathrm{h}^{-1}$ and after $24 \mathrm{~h}$ the sample gained $1.64 \%$ of the initial length. The expansion rate of the sample held at $1000{ }^{\circ} \mathrm{C}$ was ca. $23.8 \times 10^{-3} \% \times \mathrm{h}^{-1}$ and after $24 \mathrm{~h}$ the sample gained $2.63 \%$ of the initial length. 


\subsection{Wettability Tests}

As substrates with modified surfaces cannot be polished, their roughness needs to be determined experimentally. The linear and surficial characteristics and the developed area ratios for the W_850 and W_0 substrates are shown in Table 6.

Table 6. Roughness characteristics of 316L-40MgO composite substrates according to ISO 25178-2-2020 and DIN EN ISO 4287 [40,42].

\begin{tabular}{ccccccc}
\hline $\begin{array}{c}\text { Sample } \\
-\end{array}$ & $\lambda \mathbf{c}$ & $\mathbf{R a}$ & $\mathbf{R z}$ & $\begin{array}{c}\text { Sa } \\
\boldsymbol{\mu m}\end{array}$ & $\begin{array}{c}\text { Sz } \\
\boldsymbol{\mu m}\end{array}$ & $\begin{array}{c}\mathrm{Sr} \\
-\end{array}$ \\
\hline W_0 & 0.8 & 1.14 & 9.06 & 1.28 & 57.27 & 1.063 \\
W_850 & 2.5 & 3.56 & 31.15 & 3.78 & 67.62 & 1.444 \\
\hline
\end{tabular}

As expected, the pre-oxidation of the $\mathrm{W} \_850$ substrate resulted in increased roughness of the surface. The $S_{\mathrm{r}}$ parameter, which is necessary for the calculation of the equilibrium wetting angle, changed from 1.063 to 1.444 . The wetting angles were measured $30 \mathrm{~s}$ after the drop release and after $30 \mathrm{~min}$ at a temperature of $850^{\circ} \mathrm{C}$. The results of the measurement with the corresponding drop images acquired during the experiments are shown in Figure 6 and Table 7.

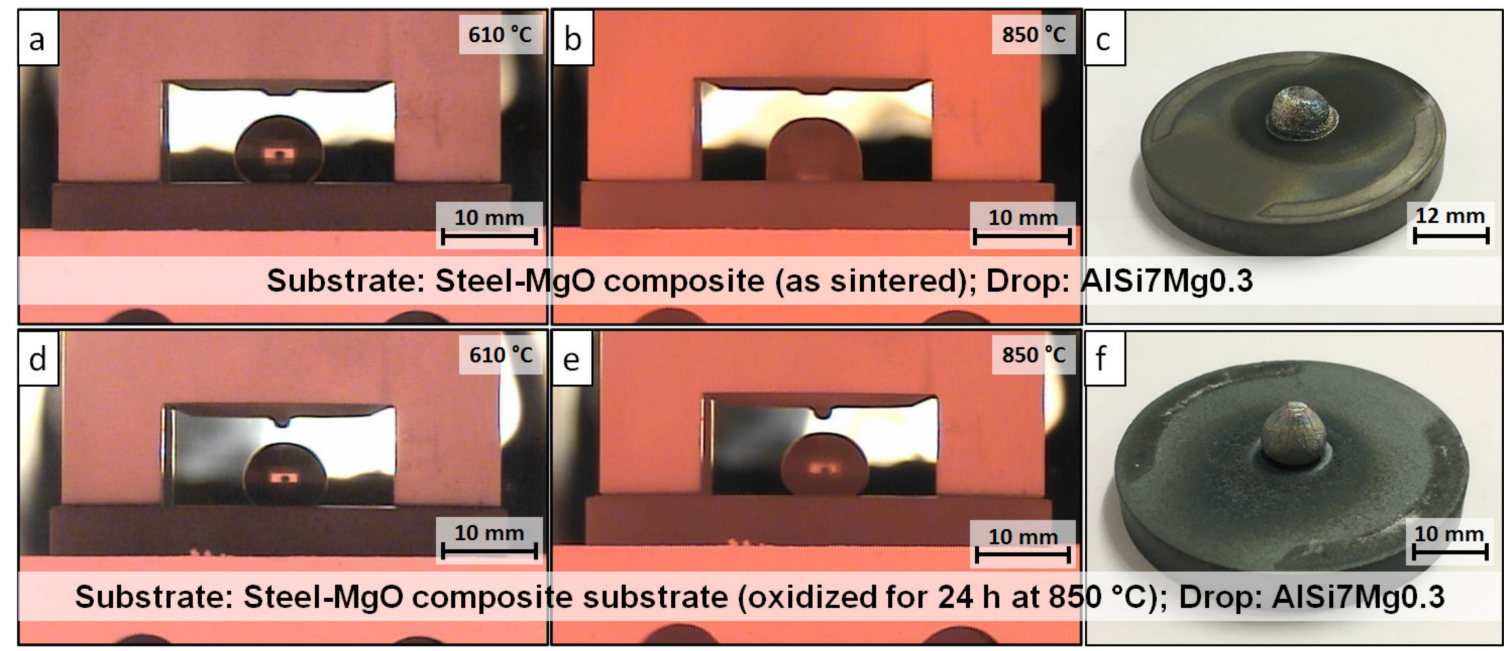

Figure 6. AlSi7Mg0.3 sessile drops on the 316L-40MgO composite substrates: (a) W_0 at the point of drop release; (b) W_0 after $30 \mathrm{~min}$ at $850{ }^{\circ} \mathrm{C}$; (c) W_0 after the test; (d) W_850 after the drop release; (e) $\mathrm{W} \_850$ after $30 \mathrm{~min}$ at $850{ }^{\circ} \mathrm{C}$; (f) W_850 after the test.

Table 7. Wetting angles between AlSi7Mg0.3 and the 316L-40MgO composite substrate.

\begin{tabular}{ccccc}
\hline Sample & \multicolumn{5}{c}{ Wetting Angle in } \\
- \\
- & $30 \mathrm{~s}$ after Release & after $\mathbf{3 0}$ min at $850{ }^{\circ} \mathbf{C}$ \\
- & $\boldsymbol{\theta}_{\mathbf{W}}$ & $\boldsymbol{\theta}_{\mathbf{E}}$ & $\boldsymbol{\theta}_{\mathbf{W}}$ & $\boldsymbol{\theta}_{\mathbf{E}}$ \\
\hline W_0 & 148.0 & 142.9 & - & - \\
W_850 & 143.0 & 123.6 & 142.0 & 123.1 \\
\hline
\end{tabular}

The calculated equilibrium wetting angles of as-sintered and pre-oxidized samples show a clear difference. The wetting angle for $\mathrm{W} \_0$ was equal to $142.9^{\circ}$, whereas for $\mathrm{W} \_850$ was smaller and equal to $123.6^{\circ}$. It is assumed that a higher wetting angle results in reduced corrosion. However, the W_0 drop reacted with the substrate after $30 \mathrm{~min}$ at $850{ }^{\circ} \mathrm{C}$. Due to the corrosion reaction, the wetting angle between the drop and the $\mathrm{W} \_0$ substrate could not be measured. The first visible reactions were observed by the change of the drop shape at $767^{\circ} \mathrm{C}$, i.e., approximately $14 \mathrm{~min}$ after the drop release. 
The W_850 sample showed a negligible change in the equilibrium wetting angle after $30 \mathrm{~min}$ at $850{ }^{\circ} \mathrm{C}$. No visible reactions of the drop with the substrate could be observed.

The overview of the samples' cross-sections after the wettability tests was achieved using laser scanning microscope (LSM) image assembly and is shown in Figure 7.

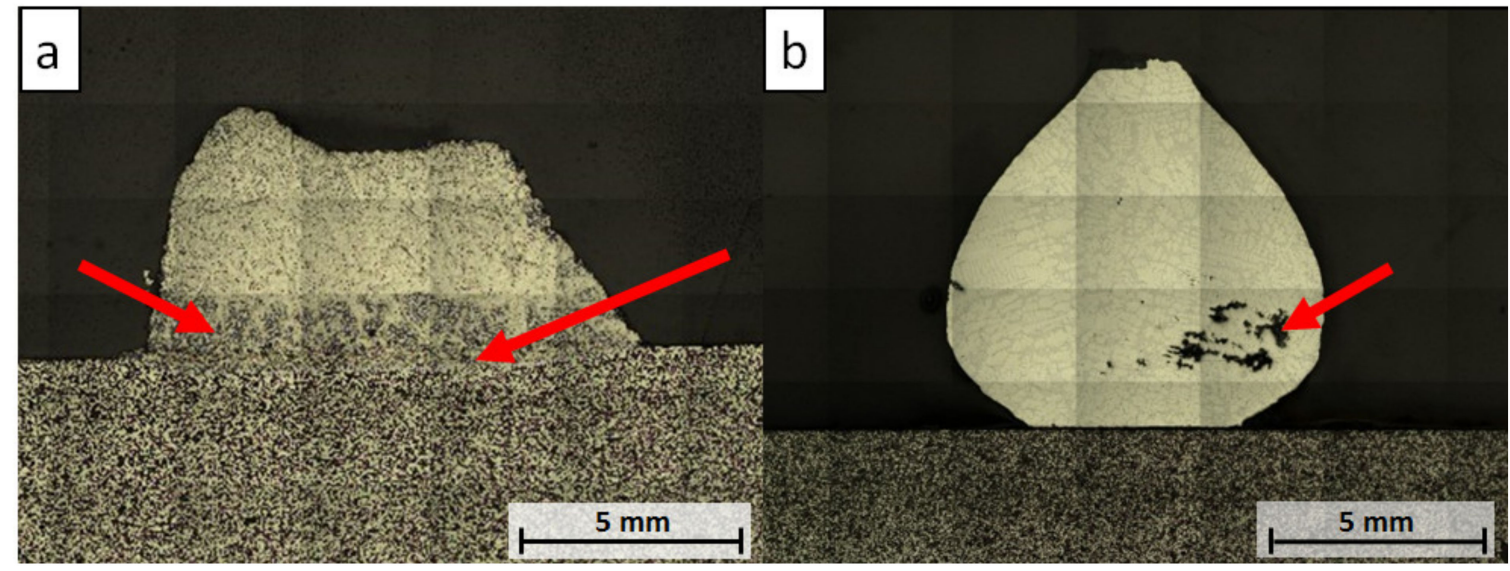

Figure 7. LSM image assembly micrographs of samples after wettability tests: (a) W_0; (b) W_850.

The collapsed drop of the W_0 sample revealed vast corrosion, with visible corrosion products being observed on the polished cross-section with the bare eye. The aluminum melt diffused into the substrate and dissolved the steel matrix, forming multiple corrosion precipitations (see red arrows, Figure 7a). For the W_850 sample, no corrosion was detected using LSM. The drop porosity indicated by the red arrow (Figure $7 \mathrm{~b}$ ) was caused by the proceeding solidification of the aluminum alloy, which started from the surface of the drop and caused the formation of such cavities.

Figure 8 and Table 8 show the microstructure of the W_0 sample and the corresponding results of EDS scans, respectively.

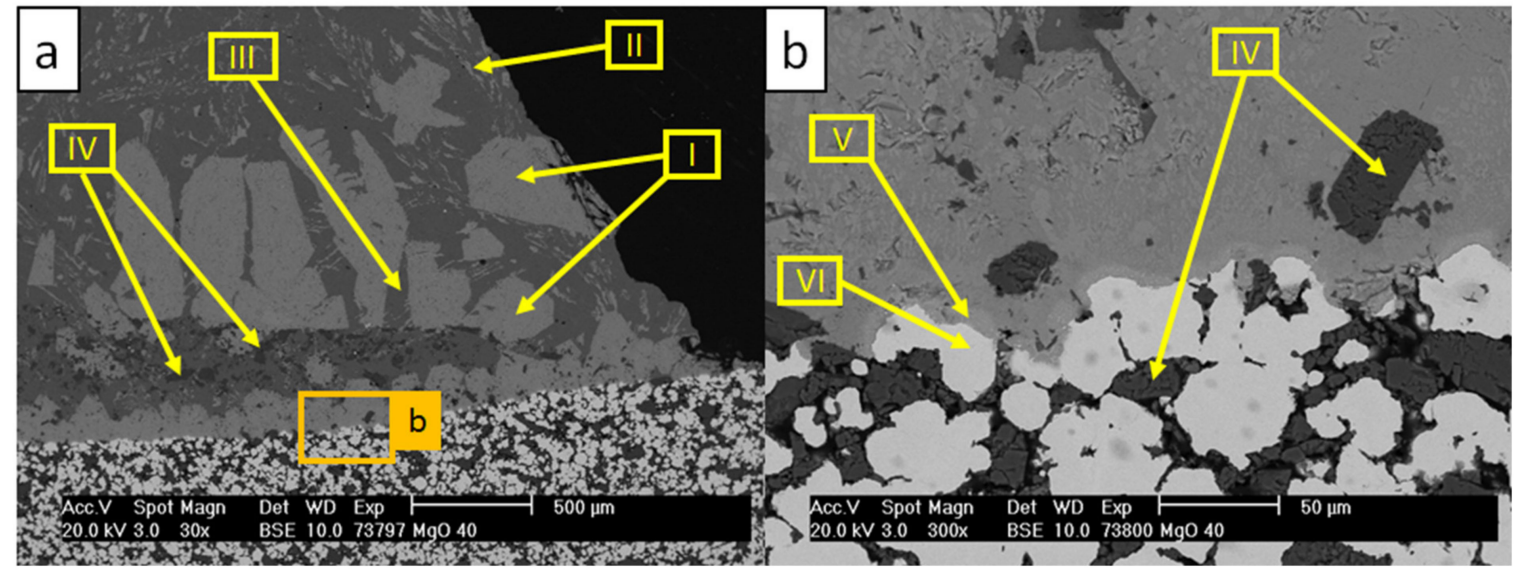

Figure 8. SEM micrographs of the W_0 sample after the corrosion test with AlSi7Mg0.3 at $850{ }^{\circ} \mathrm{C}$ : (a) image magnified to $30 \times$; (b) image magnified to $300 \times$. 
Table 8. Results of EDS scans indicated by arrows in Figure 8 (in at \%).

\begin{tabular}{cccccccccc}
\hline Scan & $\mathbf{O}$ & $\mathbf{A l}$ & $\mathbf{S i}$ & $\mathbf{F e}$ & $\mathbf{C r}$ & $\mathbf{N i}$ & $\mathbf{M n}$ & $\mathbf{M o}$ & $\mathbf{M g}$ \\
\hline I & 1.4 & 70.1 & 8.6 & 13.4 & 5.8 & - & 0.4 & 0.3 & - \\
II & - & 79.9 & 6.7 & 8.6 & - & 4.8 & - & - & - \\
III & - & 100 & - & - & - & - & - & - & - \\
IV & 53.3 & 1.0 & - & - & - & - & - & - & 45.7 \\
V & - & 76.4 & 5.2 & 13.9 & 2.7 & 1.6 & 0.2 & - & - \\
VI & - & - & - & 68.6 & 18.4 & 10.5 & 0.8 & 1.7 & - \\
\hline
\end{tabular}

The micrographs in Figure 8 showed the corroded substrate with dissolved steel particles. As a consequence of the dissolution of the matrix material, $\mathrm{MgO}$ particles diffused into the aluminum alloy drop (scan IV). Multiple new formed phases were detected in the aluminum alloy. Precipitations marked with scan I were detected as $\tau_{5}-\mathrm{Al}(\mathrm{Fe}, \mathrm{Cr}) \mathrm{Si}$ containing noticeable amounts of $\mathrm{Cr}[4,44]$. A group of flake-like precipitations from scan II was identified as $\tau_{6}$-AlFeSi $[3,4,45]$. Scans V and VI represent a steel matrix-aluminum alloy interface, where the continuous dissolution of the substrate material was revealed.

SEM analysis with the corresponding EDS scans of the W_850 sample are shown in Figure 9 and Table 9.

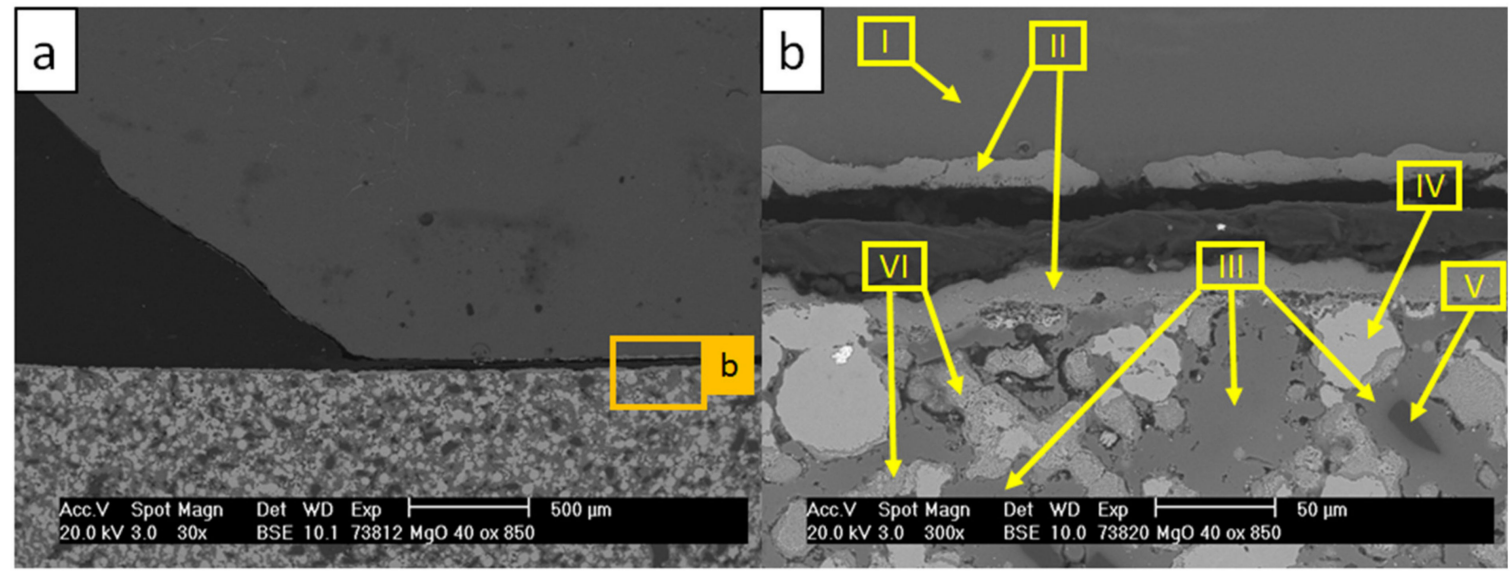

Figure 9. SEM micrographs of $\mathrm{W} \_850$ sample after the test with AlSi7Mg0.3 at $850{ }^{\circ} \mathrm{C}$ : (a) image magnified to $30 \times$; (b) image magnified to $300 \times$.

Table 9. Results of EDS scans indicated by arrows in Figure 9 (in at \%).

\begin{tabular}{cccccccccc}
\hline Scan & $\mathbf{O}$ & Al & Si & Fe & Cr & Ni & Mn & Mo & Mg \\
\hline I & - & 100 & - & - & - & - & - & - & - \\
II & 69.0 & - & - & 26.4 & - & - & - & - & 4.6 \\
III & 58.5 & - & - & 11.4 & 0.2 & - & 0.6 & - & 29.3 \\
IV & - & - & - & 68.9 & 18.5 & 10.2 & 0.8 & 1.6 & - \\
V & 58.1 & - & - & - & - & - & - & - & 41.9 \\
VI & 52.7 & - & 0.4 & 24.0 & 13.5 & 4.2 & 0.7 & 0.9 & 3.6 \\
\hline
\end{tabular}

The micrographs revealed no corrosion of the substrate. Scans I and II represent the primary aluminum from the drop with the oxide residuals from the substrate surface. Under oxidizing atmosphere in contact with steel (scan IV), the MgO particles on the surface (scan V) transformed into Mg-Fe-O mixed oxides (scan III). The steel matrix partially oxidized (scans IV and VI). No dissolution of the oxide surface was observed during the wettability tests. Taking these observations into consideration, the surface of the $316 \mathrm{~L}-40 \mathrm{MgO}$ composite after the $850{ }^{\circ} \mathrm{C}$ pre-oxidation can be described as resistant against the corrosion caused by the brief contact (approximately $30 \mathrm{~min}$ ) with the liquid aluminum alloy. 


\subsection{Crucible Corrosion Tests}

The LSM image assemblies of the cross-sections of tested crucibles are presented in Figure 10.
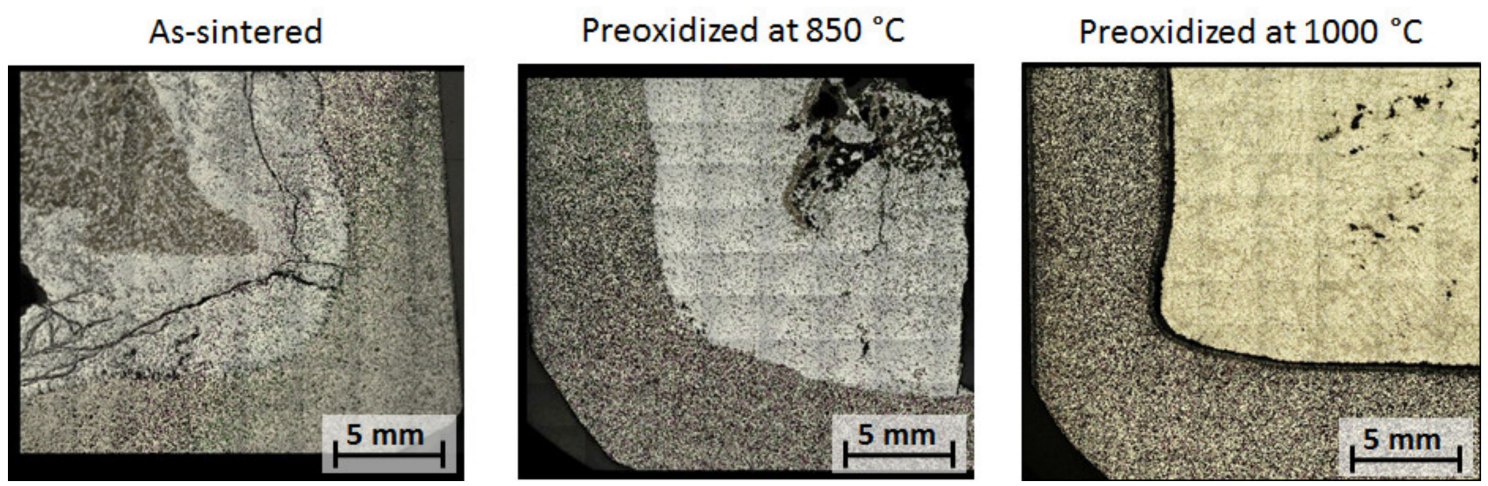

Figure 10. LSM image assembly micrographs of tested crucibles after 168 h contact with AlSi7Mg0.3 liquid aluminum alloy at $850^{\circ} \mathrm{C}$.

It was expected that the as-sintered composite crucible would dissolute over $168 \mathrm{~h}$ of contact with the liquid AlSi7Mg0.3, as the equivalent wettability substrates corroded and dissolved noticeably after 30 min contact with the alloy drop. Large fractures of the solidified alloy-crucible reaction zone were observed. During the dissolution of the matrix material, the $\mathrm{MgO}$ particles diffused into the melt and agglomerated in clusters (dark grey area in the melt). It is expected that the melt completely reacted with the steel and also reacted with the $\mathrm{MgO}$ particles, forming the $\mathrm{Mg}-\mathrm{Al}$ spinel.

The C_850 crucible corroded, dissolving in the aluminum alloy. It is assumed that this proceeded through both the dissolution and infiltration of the passivated oxide surface. The aluminum melt infiltrating the crucible reacted with the steel particles, forming new phases under the oxide film. The new formed phases caused cracking of the passivated surface and facilitated further dissolution of the crucible.

The C_1000 crucible showed no damage after $168 \mathrm{~h}$ contact with the melt. Both the melt and the crucible remained separated after solidification. A common pre-eutectic micro structure of AlSi7Mg0.3 was observed in the LSM image assembly.

\subsection{SEM and XRD Analysis of Composite Crucibles after Corrosion Tests}

The microstructure of the composite crucibles after the corrosion test with aluminum alloy is presented below. The determination of the crucible structure by XRD was performed for the C_1000 sample.

Figure 11, along with Table 10, present the SEM analysis of the crucible-aluminum alloy interface of $C_{-}$, , showing EDS scans of the most prominent phases. 


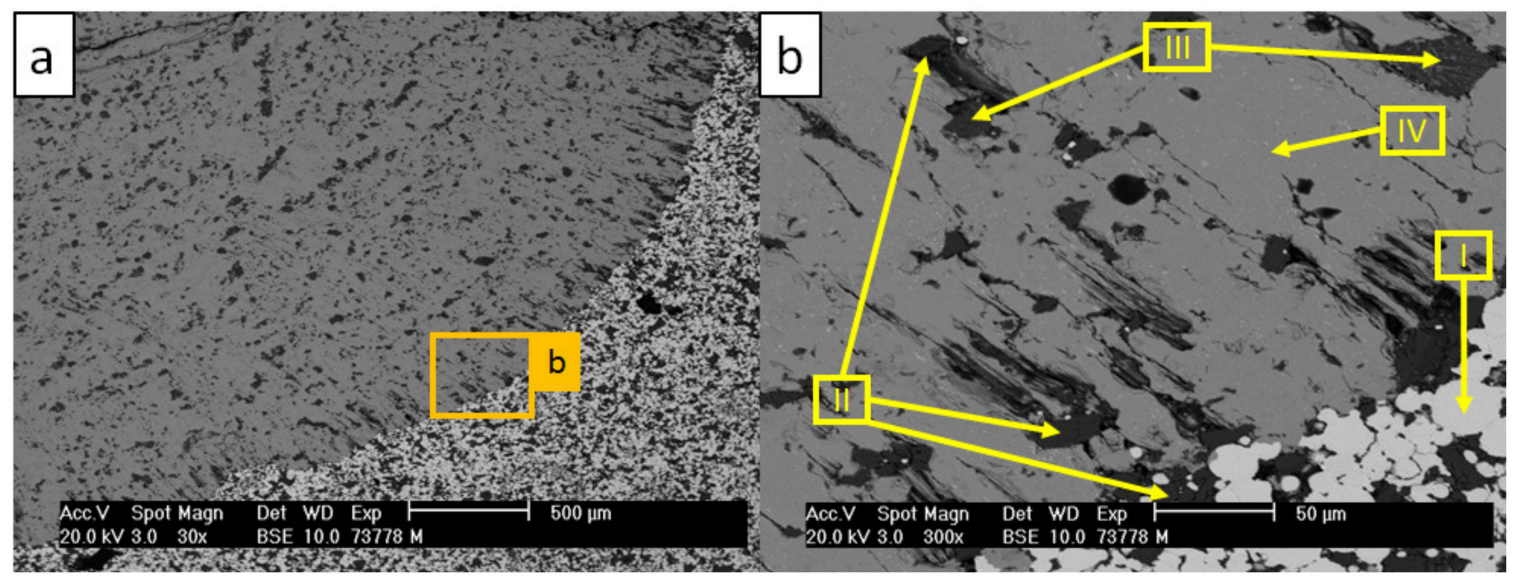

Figure 11. SEM micrographs of the C_0 composite crucible after the corrosion test with molten AlSi7Mg0.3 aluminum alloy at $850{ }^{\circ} \mathrm{C}$ : (a) image magnified to 30×; (b) image magnified to $300 \times$.

Table 10. Results of EDS scans corresponding to areas indicated by arrows in Figure 11 (in at \%).

\begin{tabular}{ccccccccccccc}
\hline Scan & $\mathbf{O}$ & $\mathbf{A l}$ & $\mathbf{S i}$ & $\mathbf{F e}$ & $\mathbf{C r}$ & $\mathbf{N i}$ & $\mathbf{M n}$ & $\mathbf{M o}$ & $\mathbf{M g}$ & $\mathbf{T i}$ & $\mathbf{N a}$ & $\mathbf{C a}$ \\
\hline I & - & - & 0.2 & 65.1 & 21.9 & 9.6 & 2.1 & 1.1 & - & - & - & - \\
II & 35.9 & - & - & 0.4 & 0.6 & 0.1 & 1.2 & - & 60.6 & - & 1.2 & - \\
III & 39.8 & 39.7 & 0.2 & 0.5 & 0.2 & 0.3 & 0.1 & - & 18.3 & - & 0.4 & 0.5 \\
IV & 1.2 & 60.9 & 4.1 & 20.7 & 6.8 & 4.8 & 0.7 & 0.2 & 0.5 & 0.1 & - & - \\
\hline
\end{tabular}

Extensive dissolution of the steel matrix into the aluminum alloy was observed in the C_0 sample. The steel reacted with the aluminum alloy melt, forming large Al-Fe-Si solid solutions with a unified composition and a relatively high amount of $\mathrm{Fe}$ (scan IV). $\mathrm{MgO}$ particles reacted with $\mathrm{Al}$ residuals and formed an $\mathrm{Al}-\mathrm{Mg}$-O oxide mixture and $\mathrm{MgAl}_{2} \mathrm{O}_{4}$ spinel (scans II and III).

Figure 12 and Table 11 present the SEM/EDS analysis of the C_850 crucible after the corrosion test at $850^{\circ} \mathrm{C}$.

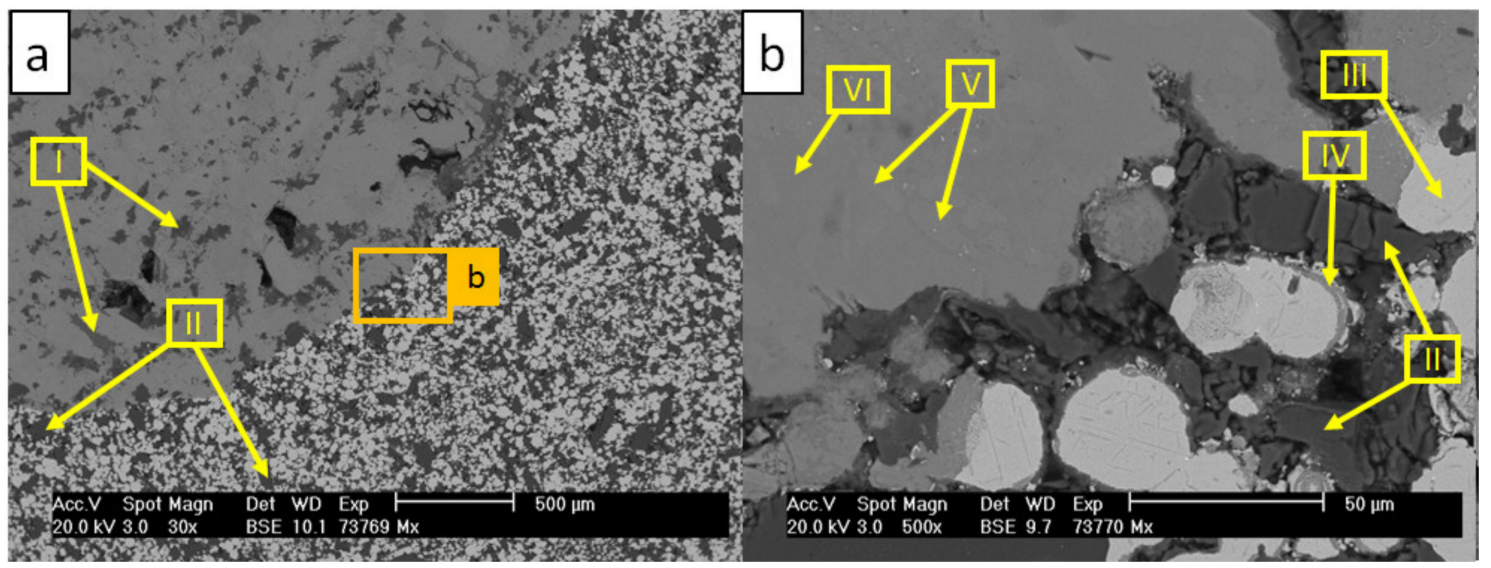

Figure 12. SEM micrographs of the C_850 composite crucible after the corrosion test with molten AlSi7Mg0.3 aluminum alloy at $850{ }^{\circ} \mathrm{C}$ : (a) image magnified to $30 \times$; (b) image magnified to $500 \times$. 
Table 11. Results of EDS scans corresponding with areas indicated by arrows in Figure 12 (in at \%).

\begin{tabular}{cccccccccccc}
\hline Scan & $\mathbf{O}$ & $\mathbf{A l}$ & $\mathbf{S i}$ & $\mathbf{F e}$ & $\mathbf{C r}$ & $\mathbf{N i}$ & $\mathbf{M n}$ & $\mathbf{M o}$ & $\mathbf{M g}$ & $\mathbf{N a}$ & $\mathbf{C a}$ \\
\hline I & 39.0 & 41.9 & 0.6 & 0.1 & 0.1 & 0.3 & 0.1 & - & 17.4 & 0.4 & 0.1 \\
II & 53.5 & - & - & - & - & - & - & - & 46.5 & - & - \\
III & - & - & 0.5 & 68.2 & 18.3 & 10.2 & 1.0 & 1.8 & - & - & - \\
IV & 65.0 & - & 0.4 & 8.2 & 15.1 & 1.1 & 2.7 & 0.7 & 7.0 & - & - \\
V & - & 76.1 & 3.3 & 16.5 & 2.2 & 1.9 & - & - & - & - & - \\
VI & - & 77.7 & 7.0 & 12.1 & 2.3 & 0.9 & - & - & - & - & - \\
\hline
\end{tabular}

Similar to the C_0 sample, the C_850 crucible corroded greatly and its steel particles dissolved in the melt. The amounts of $\mathrm{Fe}$ and $\mathrm{Cr}$ in the compositions of the corrosion phases formed with aluminum (scans V and VI) were lower in comparison to the C_0 crucible (cf. Figure 11, scan IV). The MgO particles in contact with liquid aluminum underwent a transformation to Al-Mg-O mixed oxides (scans I and II). As was assumed, the $\mathrm{MgO}-\mathrm{FeO}$ passivation layer was pushed out from the crucible vicinity during the corrosion process and was found in the upper part of the melt (Figure 13).

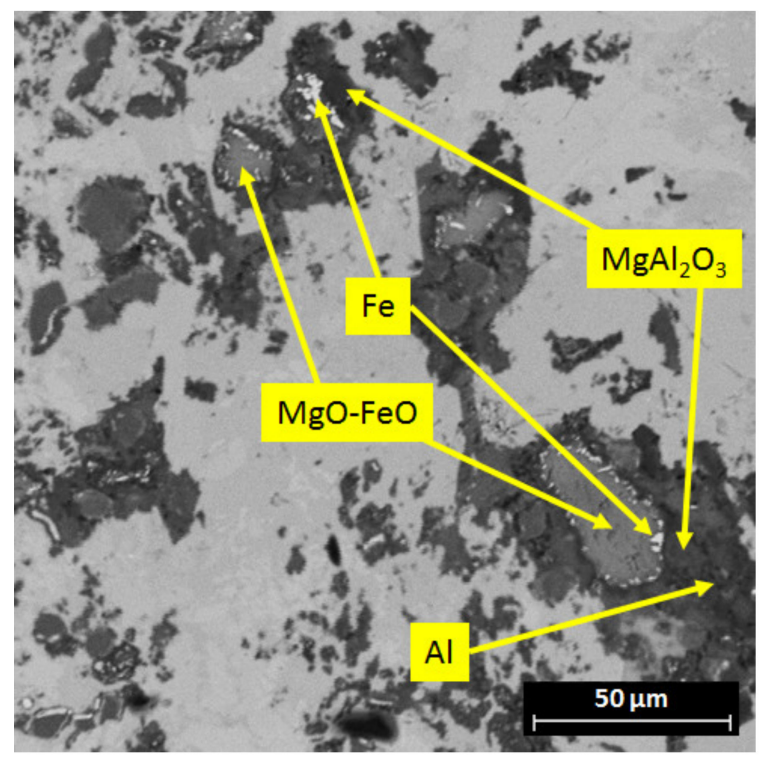

Figure 13. SEM micrograph of the $\mathrm{C}_{-} 850$ sample with decomposition of the $\mathrm{MgO}-\mathrm{FeO}$ solid solution to $\mathrm{MgAl}_{2} \mathrm{O}_{4}$ and $\mathrm{Fe}$.

The residuals of the $\mathrm{MgO}-\mathrm{FeO}$ crucible passivation layer reacted with aluminum and formed the $\mathrm{MgAl}_{2} \mathrm{O}_{4}$ spinel, reducing the Fe. The Fe precipitations could be found in the vicinity of the $\mathrm{MgO}-\mathrm{FeO}$ solid solution and $\mathrm{MgAl}_{2} \mathrm{O}_{4}$. This revealed that the passivation surface of $850^{\circ} \mathrm{C}$ pre-oxidized crucibles did undergo dissolution in contact with the liquid aluminum alloy.

Figure 14 and Table 12 present the SEM/EDS analysis of C_1000 after $168 \mathrm{~h}$ contact with the AlSi7Mg0.3 melt. 


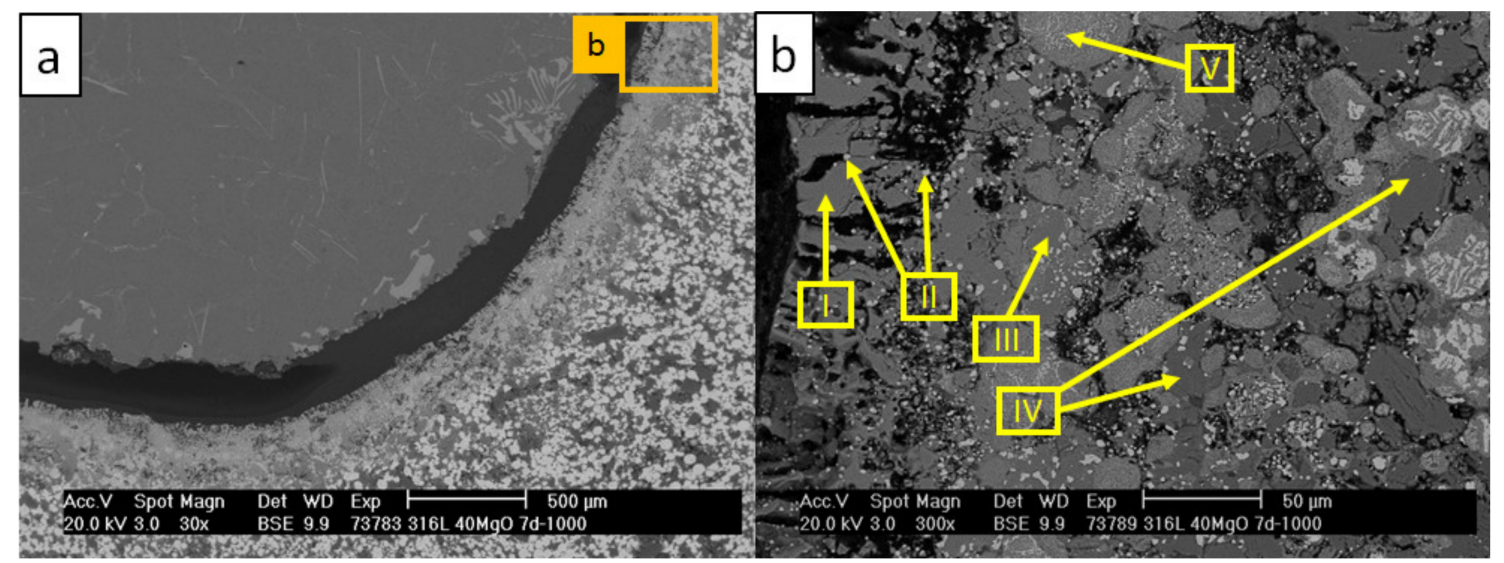

Figure 14. SEM micrographs of the C_1000 composite crucible after the corrosion test with molten AlSi7Mg0.3 aluminum alloy at $850{ }^{\circ} \mathrm{C}$ : (a) image magnified to 30×; (b) image magnified to $300 \times$.

Table 12. Results of EDS scans corresponding with areas indicated by arrows in Figure 14 (in at \%).

\begin{tabular}{cccccccccc}
\hline Scan & $\mathbf{O}$ & $\mathbf{A l}$ & $\mathbf{S i}$ & $\mathbf{F e}$ & $\mathbf{C r}$ & $\mathbf{N i}$ & $\mathbf{M n}$ & $\mathbf{M o}$ & $\mathbf{M g}$ \\
\hline I & 59.1 & - & - & 24.9 & - & - & 0.8 & - & 15.2 \\
II & 0.4 & 0.2 & 0.2 & 75.3 & 1.1 & 22.6 & - & 0.2 & - \\
III & 57.0 & - & - & 23.9 & 0.6 & 0.8 & 0.7 & - & 17.0 \\
IV & 57.0 & - & - & 12.7 & 0.6 & 0.3 & 0.3 & - & 29.1 \\
V & 61.5 & - & - & 19.0 & 10.6 & 4.5 & - & - & 4.4 \\
\hline
\end{tabular}

No damage of the crucible passivation layer was revealed after $168 \mathrm{~h}$ contact with the melt. Only minor dissolution of the surface was observed, which contributed to the formation of $\mathrm{Al}-\mathrm{Fe}-\mathrm{Si}$ precipitations in the aluminum alloy in the vicinity of the crucible surface. The crucible revealed cavities at the crucible-aluminum alloy interface. These cavities, however, were not infiltrated by the aluminum alloy (scan I). Figure 15 and Table 13 show the diffraction pattern and results of XRD-phase analysis from the surface of that crucible. 


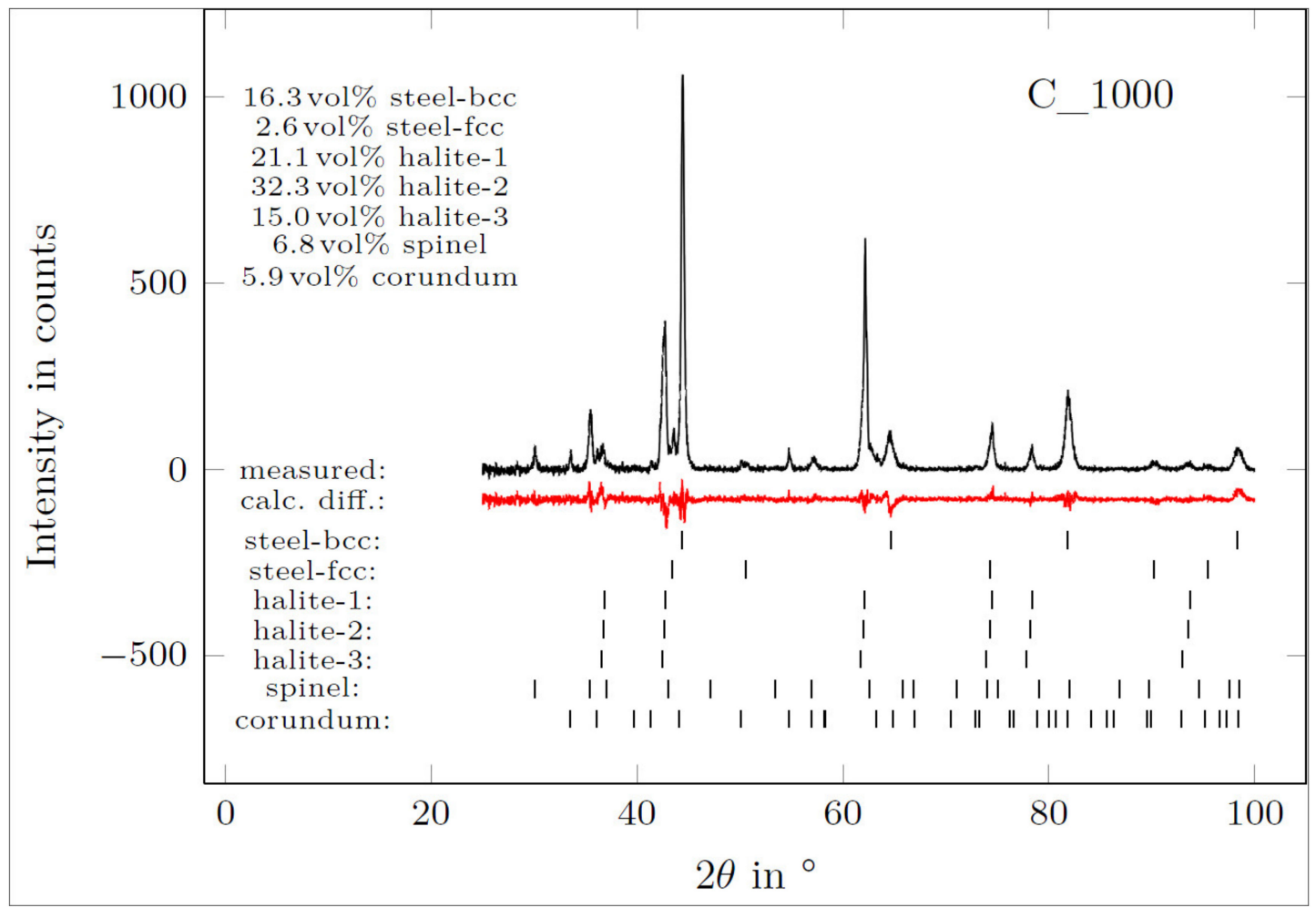

Figure 15. XRD pattern of the C_1000 crucible surface at the contact interface with aluminum alloy (detected phases designated based on their crystal structure).

Table 13. Phases detected at the surface of the C_1000 sample (designated based on their crystal structure).

\begin{tabular}{cccccc}
\hline Sample & Structure Name & Corresponding Phases & Density in $\mathbf{g} \cdot \mathbf{c m}^{-\mathbf{3}}$ & vol\% & Lattice Parameter \\
\hline C_1d_1000 & halite-1 & $\mathrm{MgO}$ & 3.56 & 21.1 & $a=4.21923 \AA$ \\
- & halite-2 & $\mathrm{MgO}-\mathrm{FeO}$ solid solution & 3.54 & 32.3 & $a=4.22753 \AA$ \\
- & halite-3 & $\mathrm{MgO}-\mathrm{FeO}$ solid solution & 3.49 & 15.0 & $a=4.24678 \AA$ \\
- & steel-bcc & $\gamma$-Fe & 7.74 & 16.3 & $a=2.88222 \AA$ \\
- & steel-fcc & $\alpha$-Fe solid solution & 7.94 & 2.6 & $a=3.60186 \AA$ \\
- & spinel & $\mathrm{Fe}_{3} \mathrm{O}_{4}$ solid solution & 5.22 & 6.8 & $a=8.38222 \AA$ \\
- & corundum & $\mathrm{Cr}_{2} \mathrm{O}_{3}$ & 5.21 & 5.9 & $a=4.96854 \AA$ \\
& & & & & $c=13.59768 \AA$ \\
\hline
\end{tabular}

Multiple MgO-FeO solid solutions with differing compositions (halite structure, cf. Table 4) were found and are presented by scans I, III, and IV [46,47]. Three halite structures were found by XRD. Halite- 1 corresponds with the $\mathrm{MgO}$ crystals, whereas halite- 2 and halite- 3 were $\mathrm{MgO}-\mathrm{FeO}$ solid solutions with 11 and $25 \mathrm{vol} \%$ of $\mathrm{FeO}$, respectively. It is assumed that halite- 2 was caused by the $\mathrm{MgO}-\mathrm{FeO}$ crystals growing epitaxially from $\mathrm{MgO}$ particles (scan IV) and that halite- 3 was the $\mathrm{MgO}-\mathrm{FeO}$ phase found near the aluminum alloy-crucible interface (scans I and III). The oxidized residuals of steel particles revealed $\mathrm{Cr}_{2} \mathrm{O}_{3}$ (corundum) and $\mathrm{Fe}_{3} \mathrm{O}_{4}$ (spinel) phases with metallic $\mathrm{Ni}$ (scan V) $[48,49]$. Among oxides, metallic Fe-Ni steel residuals were found (scan II). Only ca. $2.6 \mathrm{vol} \%$ of $\gamma$-Fe steel was found by XRD [50,51]. A detailed element mapping of aluminum-crucible contact surfaces collected over $48 \mathrm{~h}$ via ASPEX PSEM is presented in Figure 16. 


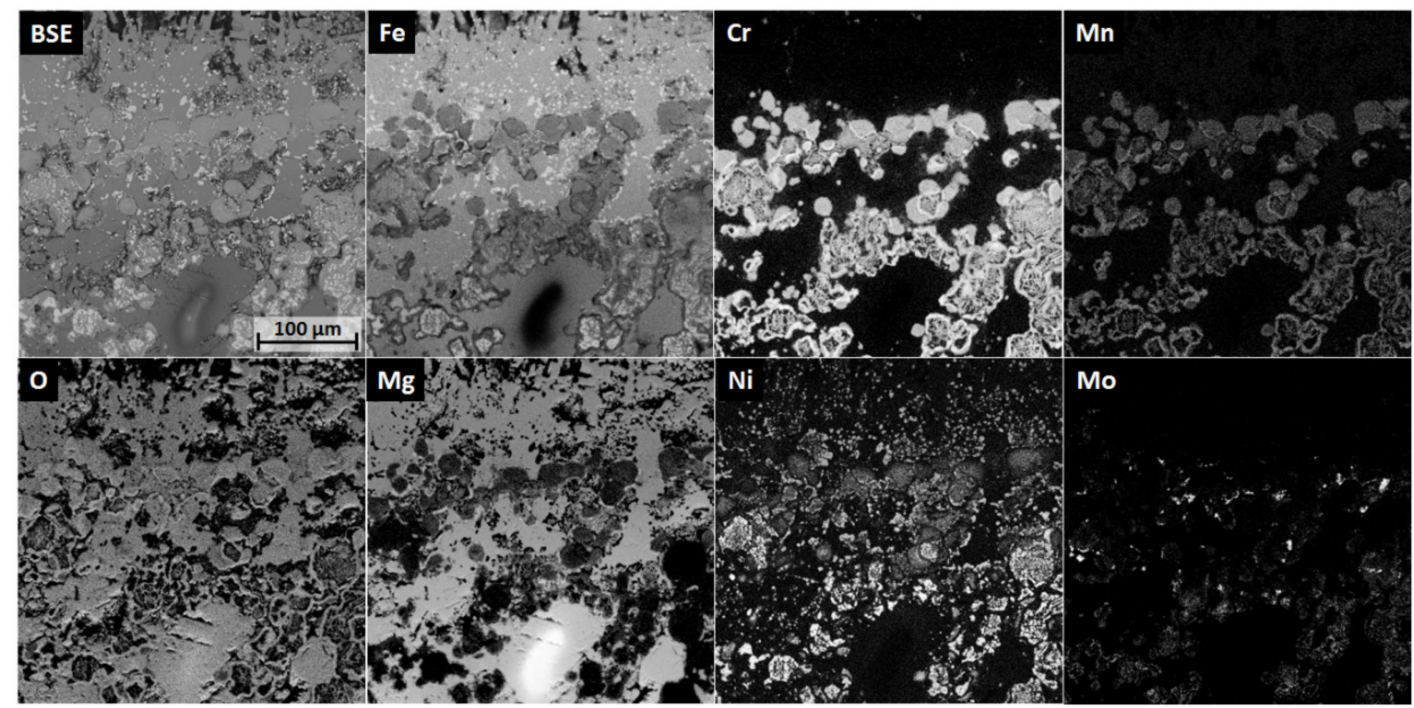

Figure 16. Detailed EDS elemental mapping at the aluminum alloy-steel-MgO composite interface of the C_1000 sample.

No dissolution of the $\mathrm{MgO}-\mathrm{FeO}$ solid solution passivation layer was observed. The Ni remained trapped in the Ni-Fe steel residuals and between the $\mathrm{Cr}_{2} \mathrm{O}_{3}$ and $\mathrm{Fe}_{3} \mathrm{O}_{4}$ mixture from oxidized steel particles. The crucible did not exhibit any damage from the contact with the liquid AlSi7Mg0.3. $\mathrm{MgO}$ particles reacting with steel during pre-oxidation at $1000{ }^{\circ} \mathrm{C}$ form a stable, homogenous passivation layer, which is resistant against long-term and high-temperature molten aluminum alloy corrosion.

\subsection{Microstructure Analysis of AlSi7Mg0.3 after Crucible Corrosion Tests}

The analysis of the aluminum alloy and the determination of the formed corrosion phases were performed on the C_1000 sample using SEM/EDS/EBSD and ASPEX PSEM/AFA methods.

The structures of the precipitating corrosion phases differed greatly depending on the distance from the crucible wall. Figures 17 and 18 and Tables 14 and 15 present the corrosion phases precipitated in the aluminum alloy at the contact boundary with the crucible.

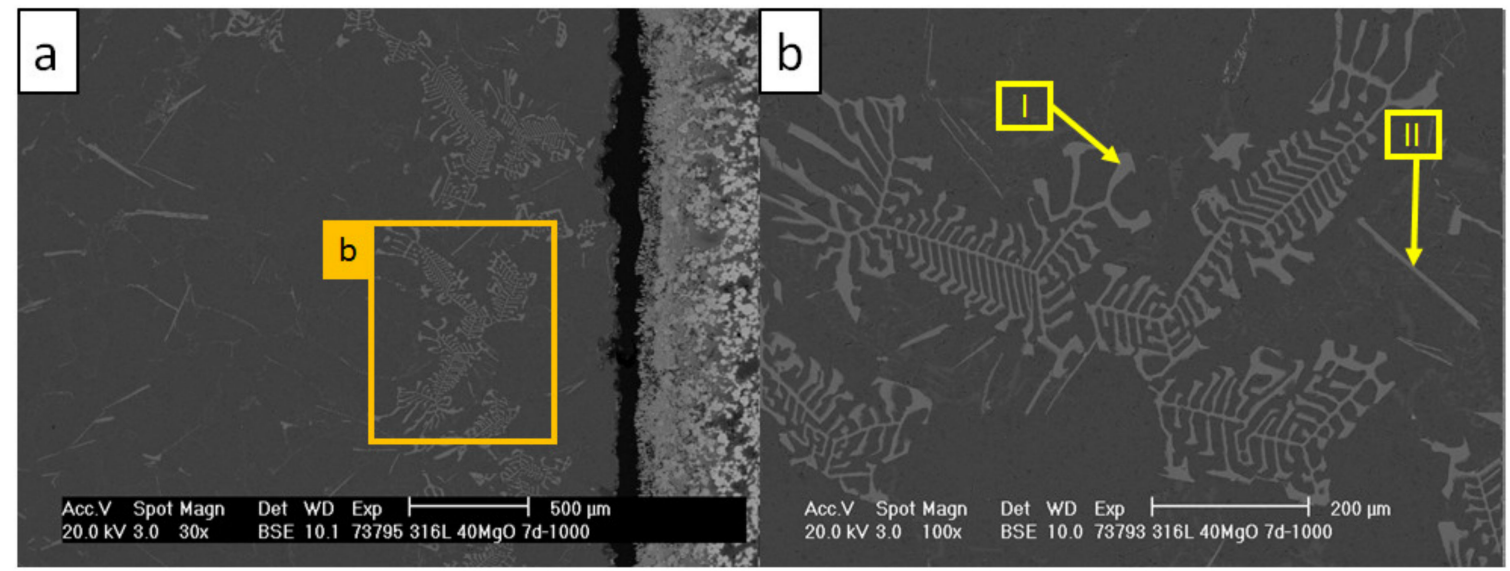

Figure 17. SEM micrographs revealing fishbone-like precipitations in AlSi7Mg0.3 close to the C_1000 interface: (a) image magnified to $30 \times$; (b) image magnified to $100 \times$. 


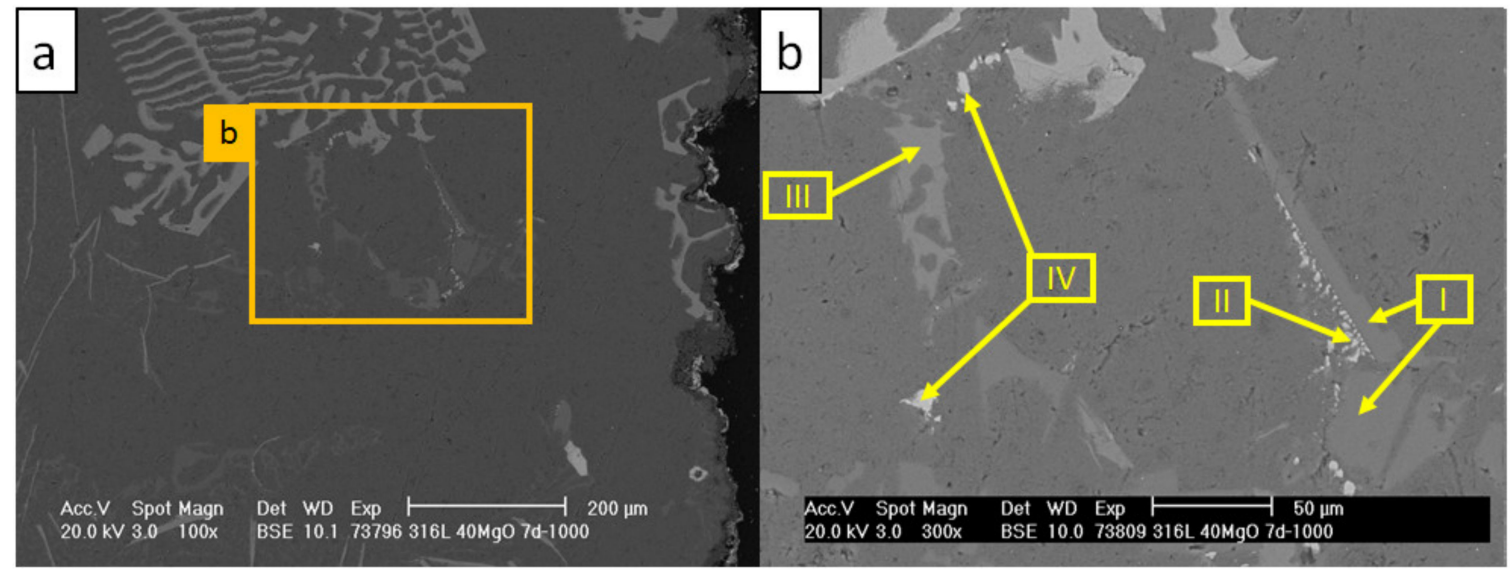

Figure 18. SEM micrographs revealing $\mathrm{Si}$ and $\mathrm{Ni}$ precipitations in AlSi7Mg0.3 in the vicinity of fishbone-like phases of C_1000: (a) image magnified to 100×; (b) image magnified to 300×.

Table 14. Results of EDS scans corresponding with areas indicated by arrows in Figure 17 (in at \%).

\begin{tabular}{ccccccc}
\hline Scan & Mg & Al & Si & Cr & Fe & Ni \\
\hline I & - & 75.9 & 10.8 & 3.5 & 9.8 & - \\
II & 0.4 & 68.9 & 12.1 & 0.3 & 17.8 & 0.5 \\
\hline
\end{tabular}

Table 15. Results of EDS scans corresponding with areas indicated by arrows in Figure 18 (in at \%).

\begin{tabular}{cccccc}
\hline Scan & Mg & Al & Si & Fe & Ni \\
\hline I & - & 4.5 & 95.5 & - & - \\
II & 1.4 & 79.7 & 12.4 & - & 6.5 \\
III & 23.1 & 45.7 & 26.3 & 2.1 & 2.9 \\
IV & 6.5 & 57.6 & 15.7 & - & 20.2 \\
\hline
\end{tabular}

At the vicinity of the crucible wall, the fishbone-like precipitations (Figure 17, scan I) were revealed. These were indicated by EBSD as $\tau_{5}-\mathrm{Al}(\mathrm{Fe}, \mathrm{Cr}) \mathrm{Si}$ phases based on the Al-Fe-Si ternary system [44]. The $\tau_{6}$-AlFeSi were found between the fishbone-like precipitations (Figure 17, scan II) [45]. In the vicinity of $\tau_{5}$, the Si- and Ni-rich precipitations (Figure 18, scans I and II, IV) and some $\pi$-AlSiMgFe phases were found (Figure 18, scan III) $[24,52,53]$. The indicated EBSD patterns of the indicated $\tau_{5}, \tau_{6}$, and $\pi$ phases are presented in Figure 19.

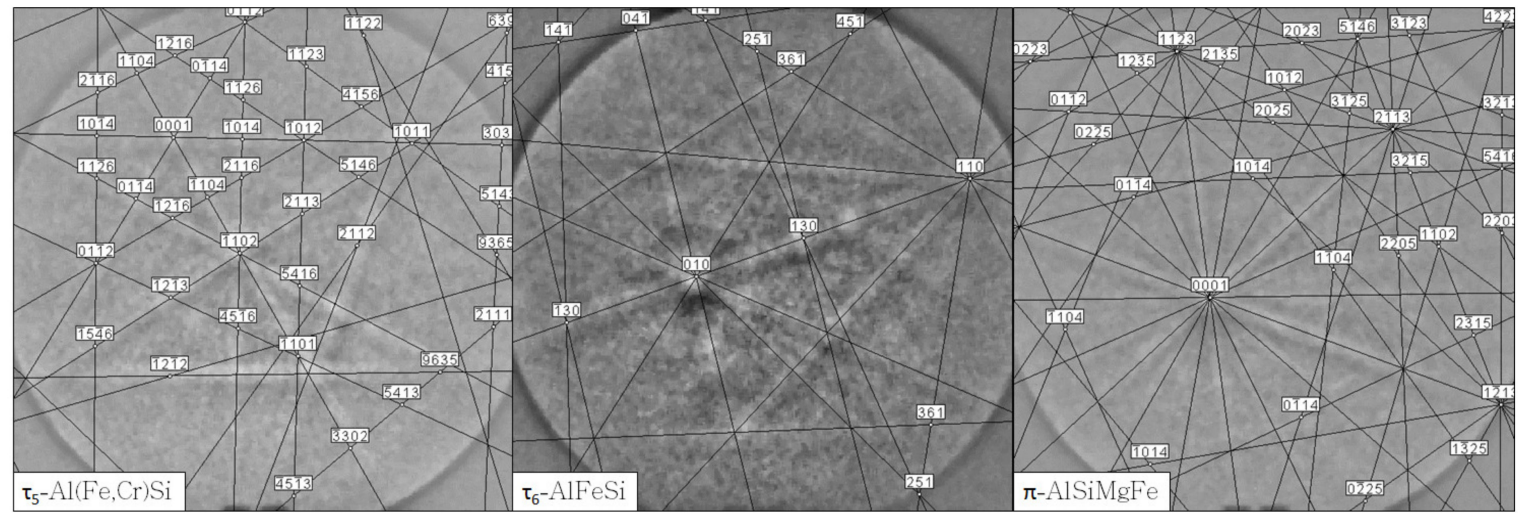

Figure 19. EBSD patterns of $\tau_{5}-\mathrm{Al}(\mathrm{Fe}, \mathrm{Cr}) \mathrm{Si}$ and $\tau_{6}$-AlFeSi phases detected in the aluminum alloy of the C_1000 sample.

Figure 20 and Table 16 present the SEM/EDS results of the internal structure of the aluminum alloy collected at $1 \mathrm{~mm}$ distance from the interface of the C_1000 sample. 


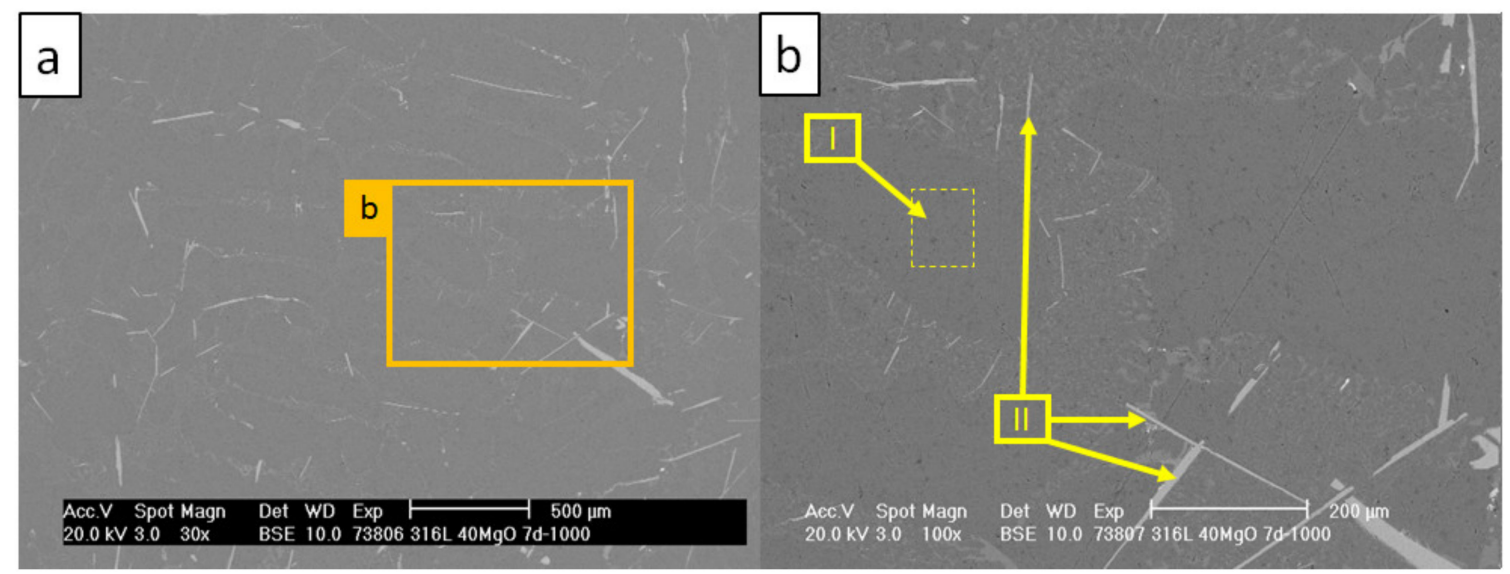

Figure 20. SEM micrographs revealing the AlSi7Mg0.3 microstructure at $1 \mathrm{~mm}$ distance from the C_1000 interface: (a) image magnified to 30×; (b) image magnified to $100 \times$.

Table 16. Results of EDS scans corresponding with areas indicated by arrows in Figure 20 (in at \%).

\begin{tabular}{ccccc}
\hline Scan & Mg & Al & Si & Fe \\
\hline I & 0.9 & 97.1 & 2.0 & - \\
II & - & 69.1 & 17.9 & 13.0 \\
\hline
\end{tabular}

EDS and EBSD scans revealed the presence of multiple long (over $500 \mu \mathrm{m}) \tau_{6}$ precipitations, which were formed among the Al-Si eutectic (scan II). Scan I presents primary Al, which did not undergo any composition change. Moreover, no $\tau_{5}$ or other corrosion phases with higher amounts of Fe or $\mathrm{Cr}$ were found beyond $1 \mathrm{~mm}$ distance from the composite crucible.

The composition of the aluminum alloy of the C_1000 sample was analyzed by collective EDS scanning of the solidified aluminum alloy. In Table 17, the results of the scan and the initial AlSi7Mg0.3 composition are listed.

Table 17. Composition of AlSi7Mg0.3 as delivered and after corrosion tests with C_1000 (in wt \%).

\begin{tabular}{ccccccccccc}
\hline Aluminum Alloy & $\mathbf{A l}$ & $\mathbf{S i}$ & $\mathbf{M g}$ & $\mathbf{F e}$ & $\mathbf{C u}$ & $\mathbf{M n}$ & $\mathbf{Z n}$ & $\mathbf{T i}$ & $\mathbf{C r}$ & $\mathbf{N i}$ \\
\hline as delivered & 92.30 & 7.17 & 0.27 & 0.081 & 0.002 & 0.002 & 0.007 & 0.12 & 0.001 & 0.003 \\
after corrosion test with C_1000 & 89.63 & 6.55 & 0.70 & 0.77 & - & 0.08 & - & 0.10 & 0.20 & 0.30 \\
\hline
\end{tabular}

The amounts of steel- and $\mathrm{MgO}$-related elements increased in relation to the total composition of the aluminum alloy by $0.5 \mathrm{wt} \%$. The Fe amount increased by $0.7 \mathrm{wt} \%$. The $\mathrm{Ni}$ and $\mathrm{Cr}$ amounts increased by $0.3 \mathrm{wt} \%$ and $0.2 \mathrm{wt} \%$, respectively. It should be mentioned that the surface-area-to volume ratio (sa/vol) plays an important role in aluminum alloy composition changes. In the presented crucible corrosion tests, the aluminum-crucible contact surface area was roughly $51 \mathrm{~cm}^{2}$, whereas the volume of aluminum placed in the crucible was approximately $36 \mathrm{~cm}^{3}$. This gives a very high $\mathrm{sa} / \mathrm{vol}$ ratio of about 1.42. In industrial environments, the casting furnaces are much larger, with an exemplary sa/vol ratio for the $1 \mathrm{~m}^{3}$ aluminum alloy equal to 0.05 , which is 28.4 times smaller than the $\mathrm{sa} / \mathrm{vol}$ ratio of the presented crucible corrosion experiment. It is obvious that the sa/vol ratio influences the density of the precipitating corrosion-related phases. For crucibles with industrial dimensions, the change of the alloy composition would be negligibly small.

The total number of corrosion-related phases precipitated in the aluminum alloy was calculated using ASPEX PSEM/AFA and is shown in Table 18. 
Table 18. Area fraction and proportion of corrosion-related phases precipitated in AlSi7Mg0.3.

\begin{tabular}{ccccccc}
\hline \multirow{2}{*}{ Sample } & Area Fraction of & \multicolumn{4}{c}{ Precipitated Corrosion-Related Phases (in \%) } \\
& Precipitations (in \%) & $\tau_{6}$-AlSiFe & $\tau_{5}$-Al(Fe,Cr)Fe & $\pi$-AlSiMgFe & Ni-rich & others \\
\hline C_1000 & 2.77 & 33.6 & 55.5 & 3.9 & 5.9 & 1.1 \\
\hline
\end{tabular}

The C_1000 sample had a total precipitation area fraction of $2.77 \%$, which consisted mostly of fishbone-like $\tau_{5}-\mathrm{Al}(\mathrm{Fe}, \mathrm{Cr}) \mathrm{Si}$ phases precipitated in the vicinity of the melt-crucible interface and $\tau_{6}$-AlFeSi phases in the middle of the melt. The sample exhibited $55.5 \%$ of $\tau_{5}-\mathrm{Al}(\mathrm{Fe}, \mathrm{Cr}) \mathrm{Si}$ and $33.6 \%$ of $\tau_{6}$-AlFeSi phases. Additionally, $3.9 \%$ of $\pi$-AlSiMgFe and $5.9 \%$ of Ni-rich phases were found. Only $1.1 \%$ of all detected corrosion-related phases remained unclassified. The $\tau_{5}$ phases contained $\mathrm{Cr}$ in their structure. No $\mathrm{Cr}$ was found in the structures of the $\tau_{6}$ and $\pi$ phases. The increased amounts of $\mathrm{Cr}$ and $\mathrm{Ni}$ in the solidified aluminum alloy indicate that the corrosion of the C_1000 crucible proceeded through dissolution of oxidized steel particles, which consisted of $\mathrm{Cr}_{2} \mathrm{O}_{3}, \mathrm{Fe}_{3} \mathrm{O}_{4}$, and metallic Ni-rich steel residuals. The low content of Mg-related $\pi$-AlSiMgFe phases is correlated with the stability of the $\mathrm{MgO}-\mathrm{FeO}$ solid solution of that crucible, which did not dissolve over $168 \mathrm{~h}$ in contact with the melt. It can be stated that the corrosion of the C_1000 crucible proceeds through the dissolution of the oxidized residuals of steel particles from the vicinity of the composite-aluminum alloy interface. The diffusion of these oxides with trapped metallic Ni forms cavities in the crucible at the contact interface with the aluminum alloy (cf. Figure 14). No dissolution of the MgO-FeO solid solution at the crucible surface was observed for this sample. It is reasonable to presume that after the dissolution of the mentioned oxidized steel particles, the composite does not dissolve further and remains fully resistant against liquid aluminum alloy.

\section{Conclusions}

A novel $316 \mathrm{~L}$ stainless steel $+40 \mathrm{vol} \% \mathrm{MgO}(316 \mathrm{~L}-40 \mathrm{MgO})$ metal matrix composite was successfully developed and manufactured by means of powder metallurgy technology. The corrosion resistance of the composite against molten AlSi7Mg0.3 aluminum alloy at a temperature of $850{ }^{\circ} \mathrm{C}$ was evaluated. The investigation of the composite surface preparation revealed the favorable influence of the surface pre-oxidation on the corrosion resistance of the composite. The pre-oxidation causes the reaction between iron and $\mathrm{MgO}$, forming $\mathrm{MgO}-\mathrm{FeO}$ solid solutions, which are stable in contact with the AlSi7Mg0.3 melt.

It was revealed that the composites without surface oxidation were not corrosion-resistant in contact with the aluminum alloy melt and corroded rapidly. The corrosion was already observed after 814 min contact with the aluminum alloy drop during the wettability tests. The corrosion of the 316L-40MgO composite occurs mainly through the dissolution of steel particles forming corrosion phases from ternary $\mathrm{Al}-(\mathrm{Fe}, \mathrm{Cr})-\mathrm{Si}$ and quaternary $\mathrm{Al}-\mathrm{Si}-\mathrm{Mg}-\mathrm{Fe}$ systems. Additionally, the $\mathrm{MgO}$ particles are not stable when in long-term contact with the liquid aluminum alloy and react to form a $\mathrm{MgAl}_{2} \mathrm{O}_{4}$ spinel.

The composite with its surface oxidized at $850{ }^{\circ} \mathrm{C}$ for $24 \mathrm{~h}$ exhibited short-term corrosion resistance against aluminum alloy, which could be observed during the wettability tests. Longer contact time with the aluminum alloy melt causes infiltration and damage of the passivation layer of the composite material.

Promising results were achieved for the composite with the surface pre-oxidized at $1000{ }^{\circ} \mathrm{C}$ for $24 \mathrm{~h}$. This composite material did not reveal any damage after $168 \mathrm{~h}$ contact with the aluminum alloy melt. Partial dissolution of the oxidized steel particles at the interface with the liquid aluminum alloy was detected. These oxides, consisting of $\mathrm{Cr}_{2} \mathrm{O}_{3}, \mathrm{Fe}_{3} \mathrm{O}_{4}$, and Ni-Fe steel residuals, caused the precipitation of $\tau_{5}-\mathrm{Al}(\mathrm{Fe}, \mathrm{Cr}) \mathrm{Si}, \tau_{6}-\mathrm{AlFeSi}, \pi-\mathrm{AlSiMgFe}$, and local Ni-rich phases in the aluminum alloy. Nevertheless, the aluminum alloy composition revealed only minor changes and the area fraction of the precipitated phases was only $2.77 \%$. Negligible dissolution of the $\mathrm{MgO}-\mathrm{FeO}$ solid solution from the composite-aluminum alloy contact interface resulted in the precipitation of $\pi$-AlSiMgFe phases. 
It can be assumed that after initial dissolution, the $316 \mathrm{~L}-40 \mathrm{MgO}$ composite remains fully resistant to the liquid aluminum alloy.

Author Contributions: Conceptualization, P.M., T.Z., and C.G.A.; methodology, P.M., T.Z., F.K., and C.W.; validation, P.M., T.Z., F.K., and C.G.A.; investigation, P.M., T.Z., F.K., C.W., S.-O.S., and H.S.; resources, T.Z., C.W., S.-O.S., H.S., and C.G.A.; writing-original draft preparation, P.M.; writing-review and editing, P.M., F.K., and C.G.A.; supervision, C.G.A.; project administration, C.W.; funding acquisition, C.G.A. All authors have read and agreed to the published version of the manuscript.

Funding: The authors gratefully acknowledge the financial support of the Federal Ministry for Economic Affairs and Energy (BMWi) for funding the research project ALUVERBUND (project number: 03ET1393B), under which the corrosion tests were carried out; and project HYMETAL (project number: 03EN2022B), under which the SEM/EBSD and ASPEX investigations were performed. Moreover, the XRD analysis was financially supported by the German Research Foundation (DFG) within the framework of the "Major Research Instrumentation" funding program (reference number: INST 267/157-1 FUGG; project number: 395259190).

Acknowledgments: The authors would like to thank C. Ludewig for the sample preparation, G. Schmidt for the SEM investigations, N. Brachhold for SEM/EBSD phase analysis, and J. Hubalkova for in-depth discussion and review.

Conflicts of Interest: The authors declare no conflict of interest.

\section{References}

1. Zhang, X.-m.; Chen, W.-p. Review on corrosion-wear resistance performance of materials in molten aluminum and its alloys. Trans. Nonferrous Met. Soc. China 2015, 25, 1715-1731. [CrossRef]

2. Balloy, D.; Tissier, J.C.; Giorgi, M.L.; Briant, M. Corrosion mechanisms of steel and cast iron by molten aluminium. Metall Mater. Trans. A Phys. Met. Mater. Sci. 2010, 41, 2366-2376. [CrossRef]

3. Zienert, T.; Fabrichnaya, O. Experimental investigation and thermodynamic assessment of the Al-Fe system. J. Alloy. Compd. 2018, 743, 795-811. [CrossRef]

4. Malczyk, P.; Weigelt, C.; Zienert, T.; Brachhold, N.; Sauke, S.-O.; Semrau, H.; Aneziris, C. Investigation of interfacial phase formation during corrosion of stainless steel. Interceram Int. Ceram. Rev. 2020, 69, 42-51. [CrossRef]

5. Barbier, F.; Manuelli, D.; Bouché, K. Characterization of aluminide coatings formed on 1.4914 and 3161 steels by hot-dipping in molten aluminium. Scr. Mater. 1997, 36, 425-431. [CrossRef]

6. Zhan, Z.; Liu, Z.; Liu, J.; Li, L.; Li, Z.; Liao, P. Microstructure and high temperature corrosion behaviors of aluminide coatings by low-temperature pack aluminizing process. Appl. Surf. Sci. 2010, 256, 3874-3879. [CrossRef]

7. Wang, D.; Shi, Z. Aluminizing and oxidation treatment of $1 \mathrm{cr} 18$ ni9 stainless steel. Appl. Surf. Sci. 2004, 227, 255-260. [CrossRef]

8. Frutos, E.; González-Carrasco, J.; Capdevila, C.; Jiménez, J.; Houbaert, Y. Development of hard intermetallic coatings on austenitic stainless steel by hot dipping in an Al-Si alloy. Surf. Coat. Technol. 2009, 203, 2916-2920. [CrossRef]

9. Sundqvist, M.; Hogmark, S. Effects of liquid aluminium on hot-work tool steel. Tribol. Int. 1993, 26, $129-134$. [CrossRef]

10. Sobczak, N.; Singh, M.; Asthana, R. High-temperature wettability measurements in metal/ceramic systems some methodological issues. Curr. Opin. Solid State Mater. Sci. 2005, 9, 241-253. [CrossRef]

11. Shi, L.-X.; Shen, P.; Zhang, D.; Jiang, Q.-C. Wetting and evaporation behaviors of molten Mg-Al alloy drops on partially oxidized $\alpha$-SiC substrates. Mater. Chem. Phys. 2011, 130,1125-1133. [CrossRef]

12. Sobczak, N.; Kudyba, A.; Siewiorek, A.; Homa, M.; Nowak, R.; Bruzda, G.; Sobczak, J.; Turalska, P.; Tchorz, A.; Andrzej, G.; et al. Textile Reinforced Carbon Fibre/Aluminium Matrix Composites for Lightweight Applications, Gude, M., Boczkowska, A., Eds.; Foundry Research Institute: Cracow, Poland, 2014; pp. 77-137. ISBN 978-83-88770-97-5.

13. Shen, P.; Nose, M.; Fujii, H.; Nogi, K. Wettability of TiAlN fims by molten aluminium. Thin Solid Films 2006, 515, 2009-2014. [CrossRef]

14. Eustathopoulos, N.; Voytovych, R. The role of reactivity in wetting by liquid metals: A review. J. Mater. Sci. 2016, 51, 425-437. [CrossRef]

15. Wenzel, R.N. Resistance of solid surfaces to wetting by water. Ind. Eng. Chem. 1936, 28, 988-994. [CrossRef] 
16. Song, X.; Bian, X.; Zhang, J.; Zhang, J. Temperature-dependent viscosities of eutectic Al-Si alloys modified with Sr and P. J. Alloy. Compd. 2009, 479, 670-673. [CrossRef]

17. Ferreira, I.; de Castro, J.; Garcia, A. Dependence of Surface Tension and Viscosity on Temperature in Multicomponent Alloys, Wettability and Interfacial Phenomena-Implications for Material Processing. Khanna, R. Ed.; IntechOpen Limited: London, UK, 2019; ISBN 978-1-83880-539-5. [CrossRef]

18. Battezzati, L.; Greer, A. The viscosity of liquid-metals and alloys. Acta Metall. 1989, 37, 1791-1802. [CrossRef]

19. Wang, Z.; Maotsela, T.; Toperesu, P.M.; Kale, G.M.; Daji, J.; Parkinson, D. Dynamic and static corrosion of alpha-alumina bonded refractory in contact with molten soda-lime-silica (sls) glass. Ceram. Int. 2019, 45, 725-732. [CrossRef]

20. Chen, G.; Wang, J.; Fan, H.; Wang, D.; Li, X.; Dong, H. Combat molten aluminum corrosion of AISI H13 steel by low-temperature liquid nitrocarburizing. J. Alloy. Compd. 2019, 776, 702-711. [CrossRef]

21. Aksel, C. The microstructural features of an alumina-mullite-zirconia refractory material corroded by molten glass. Ceram. Int. 2003, 29, 305-309. [CrossRef]

22. Wang, W.; Xue, L.; Zhang, T.; Zhou, L.; Chen, J.; Pan, Z. Thermodynamic corrosion behavior of $\mathrm{Al}_{2} \mathrm{O}_{3}$, $\mathrm{ZrO}_{2}$ and $\mathrm{MgO}$ refractories in contact with high basicity refining slag. Ceram. Int. 2019, 45, 20664-20673. [CrossRef]

23. Sellers, R.S.; Cheng, W.-J.; Kelleher, B.C.; Anderson, M.H.; Sridharan, K.; Wang, C.-J.; Allen, T.R. Corrosion of 316L stainless steel alloy and hastelloy-n superalloy in molten eutectic LiF-NaF-KF salt and interaction with graphite. Nucl. Technol. 2014, 188, 192-199. [CrossRef]

24. Zienert, T.; Fabrichnaya, O. Phase relations in the A356 alloy: Experimental study and thermodynamic calculations. Adv. Eng. Mater. 2013, 15, 1244-1250. [CrossRef]

25. Becker, H.; Bergh, T.; Vullum, P.E.; Leineweber, A.; Li, Y. $\beta$-and $\delta$-Al-Fe-Si intermetallic phase, their intergrowth and polytype formation. J. Alloy. Compd. 2019, 780, 917-929. [CrossRef]

26. Cheng, W.-J.; Wang, C.-J. EBSD study of crystallographic identification of Fe-Al-Si intermetallic phases in Al-Si coating on Cr-Mo steel. Appl. Surf. Sci. 2011, 257, 4637-4642. [CrossRef]

27. Barmak, K.; Dybkov, V. Interaction of iron-chromium alloys containing 10 and 25 mass $\%$ chromium with liquid aluminium, part I: Dissolution kinetics. J. Mater. Sci. 2003, 38, 3249-3255. [CrossRef]

28. Barmak, K.; Dybkov, V. Interaction of iron-chromium alloys containing 10 and 25 mass \% chromium with liquid aluminium, part II formation of intermetallic compounds. J. Mater. Sci. 2003, 39, 4219-4230. [CrossRef]

29. Dybkov, V. Interaction of $18 \mathrm{Cr}-10 \mathrm{Ni}$ stainless steel with liquid aluminium. J. Mater. Sci. 1990, 25, 3615-3633. [CrossRef]

30. Stratton, P. Ellingham diagrams-their use and misuse. Int. Heat Treat. Surf. Eng. 2013, 7, 70-73. [CrossRef]

31. Molinari, A.; Pellizzari, M.; Straffelini, G.; Pirovano, M. Corrosion behaviour of a surface-treated AISI H11 hot work tool steel in molten aluminium alloy. Surf. Coat. Technol. 2000, 126, 31-38. [CrossRef]

32. Ramos-Masana, A.; Colominas, C. Evaluation of DC-MS and HiPIMS TiB 2 and TaN coatings as diffusion barriers against molten aluminum: An insight into the wetting mechanism. Surf. Coat. Technol. 2019, 375, 171-181. [CrossRef]

33. Aneziris, C.G.; Dudczig, S.; Gerlach, N.; Berek, H.; Veres, D. Thermal Shock Performance of Fine Grained $\mathrm{Al}_{2} \mathrm{O}_{3}$ Ceramics With $\mathrm{TiO}_{2}$ and $\mathrm{ZrO}_{2}$ Additions for Refractory Applications. Adv. Eng. Mater. 2010, 12, 478-485. [CrossRef]

34. Fruhstorfer, J.; Schafföner, S.; Werner, J.; Wetzig, T.; Schöttler, L.; Aneziris, C.G. Thermal Shock Performance of Refractories for Application in Steel Ingot Casting. J. Ceram. Sci. Technol. 2016, 7, 173-182. [CrossRef]

35. Weigelt, C.; Brachhold, N.; Eckner, R.; Krüger, L.; Hauser, M.; Sauke, S.; Semrau, H.; Aneziris, C.G. Metal-Matrix Materials for High-Temperature Applications with Liquid Aluminum. Adv. Eng. Mater. 2020, 22, 1-11. [CrossRef]

36. Chong, J.Y.; Wang, B.; Li, K. High performance stainless steel-ceramic composite hollow fibres for microfiltration. J. Membr. Sci. 2017, 541, 425-433. [CrossRef]

37. Misra, D.; Barange, S.; Joardar, H.; Kumar, J.; Das, A.K.; Mukhopadhyay, S.; Chatterjee, S. Comparative study on the tribological properties of laser post-treated and untreated AISI304 stainless steel matrix composite reinforced with hard ceramic particles $\left(\mathrm{TiB}_{2}\right.$ TiN_SiC) and prepared by ex-situ p/m route. Ceram. Int. 2019, 45, 18852-18864. [CrossRef] 
38. Weigelt, C.; Schmidt, G.; Aneziris, C.; Eckner, R.; Ehinger, D.; Krüger, L.; Ullrich, C.; Rafaja, D. Compressive and tensile deformation behaviour of trip steel-matrix composite materials with reinforcing additions of zirconia and/or aluminium titanate. J. Alloy. Compd. 2017, 695, 9-20. [CrossRef]

39. Fabrichnaya, O. The assessment of thermodynamic parameters for solid phases in the Fe-Mg-O and Fe-Mg-Si-O systems. Calphad 1998, 22, 85-125. [CrossRef]

40. ISO 25178-2-2020. Geometrical Product Specifications (GPS)-Surface Texture: Areal-Part 2: Terms, Definitions and Surface Texture Parameters; Beuth Verlag: Berlin, Germany, 2020.

41. Zienert, T.; Dudczig, S.; Malczyk, P.; Brachhold, N.; Aneziris, C.G. Characterization of the In Situ-Formed Oxide Layer at the Steel Melt/Carbon-Bonded Alumina Interface. Adv. Eng. Mater. 2020, 22, 1-11. [CrossRef]

42. DIN EN ISO 4287:2010-07. Geometrical Product Specifications (GPS)-Surface Texture: Profile Method-Terms, Definitions and Surface Texture Parameters; Beuth Verlag: Berlin, Germany, 2010.

43. DIN EN 10088-1:2014-12. Stainless Steels-Part 1: List of Stainless Steels, Appendix, E; Beuth Verlag: Berlin, Germany, 2014.

44. Roger, J.; Bosselet, F.; Viala, J.C. Structural chemistry and thermal stability of the ternary compound alpha-AlFeSi. J. Solid State Chem. 2011, 184, 1120-1128. [CrossRef]

45. Hansen, V.; Hauback, B.C.; Sundberg, M.; Romming, C.; Gjonnes, J. $\beta$-Al4.5FeSi: A combined synchrotron powder diffraction, electron diffraction, high resolution electron microscopy and single-crystal X-ray diffraction study of a faulted structure. Acta Crystallogr. B 1998, 54, 351-357. [CrossRef]

46. Tsirelson, V.G.; Avilov, A.S.; Abramov, Y.A.; Belokoneva, E.L.; Kitaneh, R.; Feil, D. X-ray and electron diffraction study of MgO. Acta Crystallogr. B 1998, 54, 8-17. [CrossRef]

47. Jette, E.R.; Foote, F. An x-ray study of the wüstite (feo) solid solutions. J. Chem. Phys. 1933, 1, 29-36. [CrossRef]

48. Newnham, R.E.; de Haan, Y.M. Refinement of the $\alpha \mathrm{Al}_{2} \mathrm{O}_{3}, \mathrm{Ti}_{2} \mathrm{O}_{3}, \mathrm{~V}_{2} \mathrm{O}_{3}$ and $\mathrm{Cr}_{2} \mathrm{O}_{3}$ structures. Z. Kristallogr. Cryst. Mater. 1962, 117, 235-237. [CrossRef]

49. Fleet, E. The structure of magnetite: Symmetry of cubic spinels. J. Solid State Chem. 1986, 1, 75-82. [CrossRef]

50. Straumanis, M.E.; Kim, D.C. Lattice constants, thermal expansion coefficients, densities, and perfection of structure of pure iron and of iron loaded with hydrogen. Z. Met. 1969, 60, 272-277. [CrossRef]

51. Owen, E.A.; Yates, E.L. Precision measurements of crystal parameters. Philos. Mag. 1933, 15, 472-488. [CrossRef]

52. Foss, S.; Olsen, A.; Simensen, C.J.; Tafto, J. Determination of the crystal structure of the $\pi-(\mathrm{AlFeMgSi})$ phase using symmetry- and site-sensitive electron microscope techniques. Acta Crystallogr. B 2003, 59, 36-42. [CrossRef] [PubMed]

53. Raghavan, V. Al-Fe-Mg-Si (aluminum-iron-magnesium-silicon). J. Phase Equilibria Diffus. 2007, $28,213-214$. [CrossRef]

Publisher's Note: MDPI stays neutral with regard to jurisdictional claims in published maps and institutional affiliations.

(C) 2020 by the authors. Licensee MDPI, Basel, Switzerland. This article is an open access article distributed under the terms and conditions of the Creative Commons Attribution (CC BY) license (http://creativecommons.org/licenses/by/4.0/). 